\title{
ANNUAL REPORT TO CONGRESS
}

\author{
Department of Energy Activities \\ Relating to the \\ Defense Nuclear Facilities Safety Board
}

Calendar Year 2000

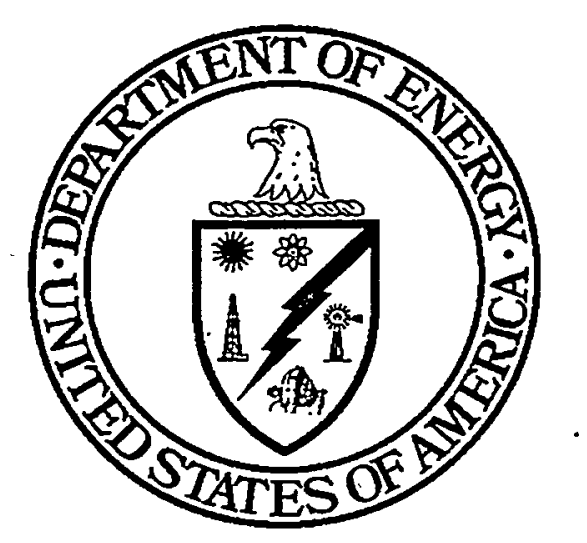

Washington, D.C. 20585

March 2001 


\section{DISCLAIMER}

This report was prepared as an account of work sponsored by an agency of the United States Government. Neither the United States Government nor any agency thereof, nor any of their employees, make any warranty, express or implied, or assumes any legal liability or responsibility for the accuracy, completeness, or usefulness of any information, apparatus, product, or process disclosed, or represents that its use would not infringe privately owned rights. Reference herein to any specific commercial product, process, or service by trade name, trademark, manufacturer, or otherwise does not necessarily constitute or imply its endorsement, recommendation, or favoring by the United States Government or any agency thereof. The views and opinions of authors expressed herein do not necessarily state or reflect those of the United States Government or any agency thereof. 


\section{DISCLAIMER}

Portions of this document may be illegible in electronic image products: Images are produced from the best available original document. 


\section{The Secretary of Energy \\ Washington, DC 20585}

March 15, 2001

The Honorable Richard B. Cheney

President of the Senate

Washington, D.C. 20510

Dear Mr. President:

I am pleased to submit the Department's Annual Report to Congress for Calendar Year 2000 entitled Department of Energy Activities Relating to the Defense Nuclear Facilities Safety Board, which is required by Section 316(b) of the Atomic Energy Act of 1954.

During 2000, the Department completed its implementation of and proposed closure of one Defense Nuclear Facilities Safety Board (Board) recommendation and completed all implementation plan milestones associated with two additional Board recommendations. In 2000, the Department formally accepted two new recommendations received from the Board and developed implementation plans in response to those recommendations.

The Department has also made significant progress in carrying over a number of broad-based initiatives to improve safety. These include the largely completed initial implementation of integrated safety management at field sites and within Headquarters program offices, issuance of a nuclear safety rule, and preparing a revised plan for stabilizing excess nuclear materials to achieve significant risk reduction.

If you have any questions, please contact me or have a member of your staff contact Mr. Mark B. Whitaker, Jr., Departmental Representative to the Board, at (202) 586-3887.

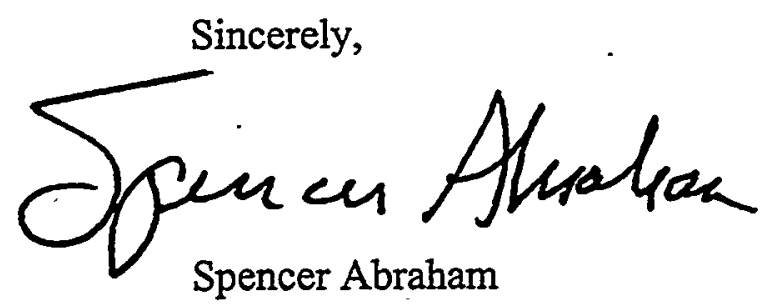

Enclosure 


\section{TABLE OF CONTENTS}

\section{LETTER TO CONGRESS}

I. EXECUTIVE SUMMARY $\ldots \ldots \ldots \ldots \ldots \ldots \ldots \ldots \ldots \ldots \ldots \ldots \ldots \ldots \ldots \ldots \ldots \ldots \ldots$

II. KEY DEPARTMENT SAFETY INITIATIVES $\ldots \ldots \ldots \ldots \ldots \ldots \ldots \ldots \ldots \ldots \ldots \ldots \ldots$ II-1

A. Operational Readiness of Vital Safety Systems $\ldots \ldots \ldots \ldots \ldots \ldots \ldots$ II -1

B. Stabilization of Excess Nuclear Materials $\ldots \ldots \ldots \ldots \ldots \ldots \ldots \ldots \ldots$ II -4

C. Nuclear Safety Rule ............................

D. Establishment of the National Nuclear Security Administration ........... II-7

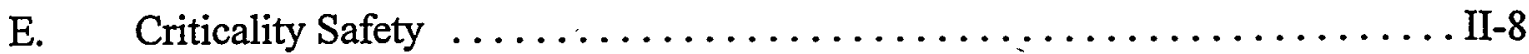

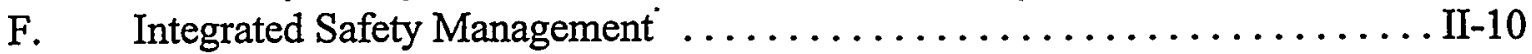

III. IMPLEMENTATION OF BOARD RECOMMENDATIONS $\ldots \ldots \ldots \ldots \ldots \ldots$ III-1

A. Recommendation Closures . ......................... III 1

B. Recommendations Previously Proposed for Closure $\ldots \ldots \ldots \ldots \ldots \ldots$ III-2

C. New Recommendation and Implementation Plan ............... III-3

D. Other Active Implementation Plans . ..................... III-6

E. Report on Implementation Plans Requiring More Than One Year ....... III-18

F. Categorization of Board Recommendations .................. III-19

IV. OTHER BOARD INTERFACE ACTIVITIES $\ldots \ldots \ldots \ldots \ldots \ldots \ldots \ldots$ IV-1

\section{APPENDICES}

A Orders and Departmental Safety Directives of Interest to the Board $\ldots \ldots \ldots \ldots$ A-1

B Site Visits Supported by the Department in $2000 \ldots \ldots \ldots \ldots \ldots \ldots \ldots$ B-1

C Key Department/Board Correspondence in $2000 \ldots \ldots \ldots \ldots \ldots \ldots \ldots$ C-1 


\section{List of Tables}

1.A Historical Trend of Open Board Recommendations $\ldots \ldots \ldots \ldots \ldots \ldots \ldots$ I-2

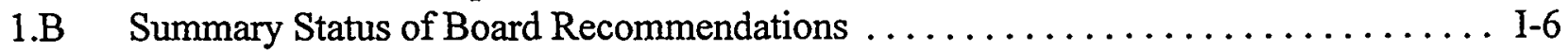

1.C Key Dates for Active Board Recommendations .................... I-7

3.A Department-Wide Recommendations . ..................... III-20

3.B Multiple-Site/Multiple-Organization Recommendations $\ldots \ldots \ldots \ldots \ldots \ldots \ldots$ III-20

3.C Single-Site/Single-Organization Recommendations $\ldots \ldots \ldots \ldots \ldots \ldots \ldots$ III-21

3.D Lead Organization: Environmental Management . . . . . . . . . . . . . . . III -21

3.E Lead Organization: Defense Programs $\ldots \ldots \ldots \ldots \ldots \ldots \ldots \ldots \ldots \ldots$ III-21

3.F Lead Organization: Other Headquarters Organizations . . . . . . . . . . . . III-22

3.G Implementation Plans Complete . ......................... III-22

3.H Implementation Plans Projected To Be Complete in $2001 \ldots \ldots \ldots \ldots \ldots$. . . . . . . 23

3.I Implementation Plans Projected To Be Complete After 2001 . . . . . . . . . . . . III-23

4.A Defense Nuclear Facilities Safety Board Year 2000 Formal Reporting Requirements IV-3

4.B Defense Nuclear Facilities Safety Board Year 2000 Public Meetings . . . . . . . . . IV-4

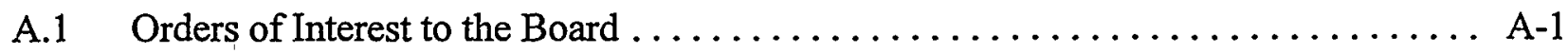

A.2 DOE Safety Directives Coordinated With The Board Staff $\ldots \ldots \ldots \ldots \ldots \ldots$ A 5 


\section{EXECUTIVE SUMMARY}

This Annual Report to the Congress describes the Department of Energy (Department) activities in response to formal recommendations and other interactions with the Defense Nuclear Facilities Safety Board (Board). The Board, an independent executive-branch agency established in 1988, provides advice and recommendations to the Secretary of Energy regarding public health and safety issues at the Department's defense nuclear facilities. The Board also reviews and evaluates the content and implementation of health and safety standards, and other requirements relating to the design, construction, operation, and decommissioning of the Department's defense nuclear facilities. Figure 1 (page I-5) provides the locations of the major Department facilities.

During 2000, the Department completed its implementation and proposed closure of one Board recommendation and completed all implementation plan milestones associated with two additional Board recommendations. Also in 2000, the Department formally accepted two new Board recommendations and developed implementation plans in response to those recommendations.

The Department also made significant progress with a number of broad-based safety initiatives. These include initial implementation of integrated safety management at field sites and within headquarters program offices, issuance of a nuclear safety rule, and continued progress on stabilizing excess nuclear materials to achieve significant risk reduction.

\section{Recommendations Nearing Closure}

Table 1.B (page I-6) provides a summary status on Board recommendations. Department activities in 2000 led to the proposed closure of one Board recommendation:

- Recommendation 94-1, Improved Schedule for Remediation (Closure proposed in June 2000.)

In addition, the Department has completed all of the milestone deliverables for four additional implementation plans:

- Recommendation 98-1, Resolution of Internal Oversight Findings

- Recommendation 95-2, Safety Management 
- $\quad$ Recommendation 97-1, Safe storage of Uranium-233 (Final commitment completed in 1999.)

- Recommendation 92-4, Multi-Function Waste Tank Facility at Hanford (Closure proposed in December 1998.)

\section{New $\mid$ Recommendations and Implementation Plans}

In 2000 the Department formally accepted two new recommendations received from the Board and developed implementation plans in response to those recommendations:

- Recommendation 2000-1, Stabilization and Storage of Nuclear Material
- Recommendation 2000-2, Configuration Management, Vital Safety Systems

Implementation plans establish the Department's approach and schedule to resolve the associated safety issues. Table 1.C (page I-7) provides key dates for active Board recommendations.

Trend in the Number of Open Board Recommendations

Table 1.A illustrates the change in the number of open Board recommendations for each year since the inception of the Board.

Table 1.A - Historical Trend of Open Board Recommendations

\begin{tabular}{|c|c|c|c|c|}
\hline Year & $\begin{array}{c}\text { Recommendations } \\
\text { Issued }\end{array}$ & $\begin{array}{c}\text { Recommendations } \\
\text { Closed }\end{array}$ & $\begin{array}{c}\text { Net Change in Open } \\
\text { Recommendations }\end{array}$ & $\begin{array}{c}\text { Open Recommendations } \\
\text { at Year End }\end{array}$ \\
\hline 1990 & 7 & 0 & +7 & 7 \\
\hline 1991 & 6 & 0 & +6 & 13 \\
\hline 1992 & 7 & 8 & -1 & 12 \\
\hline 1993 & 6 & 1 & +5 & 17 \\
\hline 1994 & 5 & 1 & +4 & 21 \\
\hline 1995 & 2 & 6 & -4 & 17 \\
\hline 1996 & 1 & 4 & -3 & 14 \\
\hline 1997 & 2 & 1 & +1 & 15 \\
\hline 1998 & 2 & 0 & +2 & 17 \\
\hline 1999 & 1 & 9 & -8 & 9 \\
\hline 2000 & 2 & 0 & +2 & 11 \\
\hline
\end{tabular}


The data in Table 1.A reflects the evolution of the recommendation process. Initially, Board recommendations addressed specific, highly technical, significant safety issues within the Department's activities. Over time, the Department has addressed these risks, and to established fundamental, integrated programs to improve the Department's overall safety management process. Department success in these areas, combined with an increased use of letters and other notification methods by the Board, has led to the issuance of fewer, often more broad-based recommendations in recent years. The Department intends to make the closure of applicable recommendations a priority in 2001. This will allow the Department to focus its resources on resolving fundamental safety issues addressed by the remaining open recommendations or identified through other interactions with the Board.

\section{Summary of the Department's Major Safety Accomplishments}

Concrete accomplishments over the past year that have contributed to improved safety at Department facilities include:

- the completion of the initial implementation of integrated safety management at all but three of the sites and facilities targeted for completion by September 2000;

- the issuance of a major revision to the Integrated Safety Management System Guide, which provides requirements guidelines to field and headquarters personnel on maintaining an effective integrated safety management system;

- the completion of a DOE-wide assessment of the effectiveness of field and headquarters implementation of a process for resolving issues identified by the Office of Oversight (EH-2); and

- the publication of the first Integrated Safety Management Department-wide performance measures and initial development of a process by which these measures would be matured and improved in the months ahead:

\section{Department Focus for 2001}

In 2001, the Department intends to stay focused on assuring that implementation plans remain valid and workable, managing actions to completion by the identified due dates, and proposing closure of recommendations when the underlying safety issues are resolved. The most significant challenges involve safety issues that are complex in nature and involve management culture changes such as: 
- initiating actions to assess and maintain the operational readiness of the Department's vital safety systems;

- improving the Department's safety management system, which integrates all elements of safety (e.g., public health, occupational safety, environmental protection) into management and work practices at all levels so that work can be accomplished while protecting the public, the worker, and the environment; and

- sustaining progress on stabilizing excess nuclear material.

The above items are long-term issues that will demand a dedicated, multi-year effort to resolve successfully. The Department is committed to these ongoing efforts and does not foresee any major shifts or re-direction in these core safety initiatives, thus providing continuity of direction for headquarters, field, and contractor organizations.

\section{Report Preview}

The remaining portions of the annual report are described below:

- Section II, KEY DEPARTMENT SAFETY INITIATIVES, describes broad-based Department activities that affect environment, safety and health;

- Section III, IMPLEMENTATION OF BOARD RECOMMENDATIONS, describes Department activities completed in 2000 to implement Board recommendations accepted by the Secretary; and

- Section IV, OTHER BOARD INTERFACE INITLATIVES, describes Department activities to maintain communications and improve interaction between the Department and the Board. 


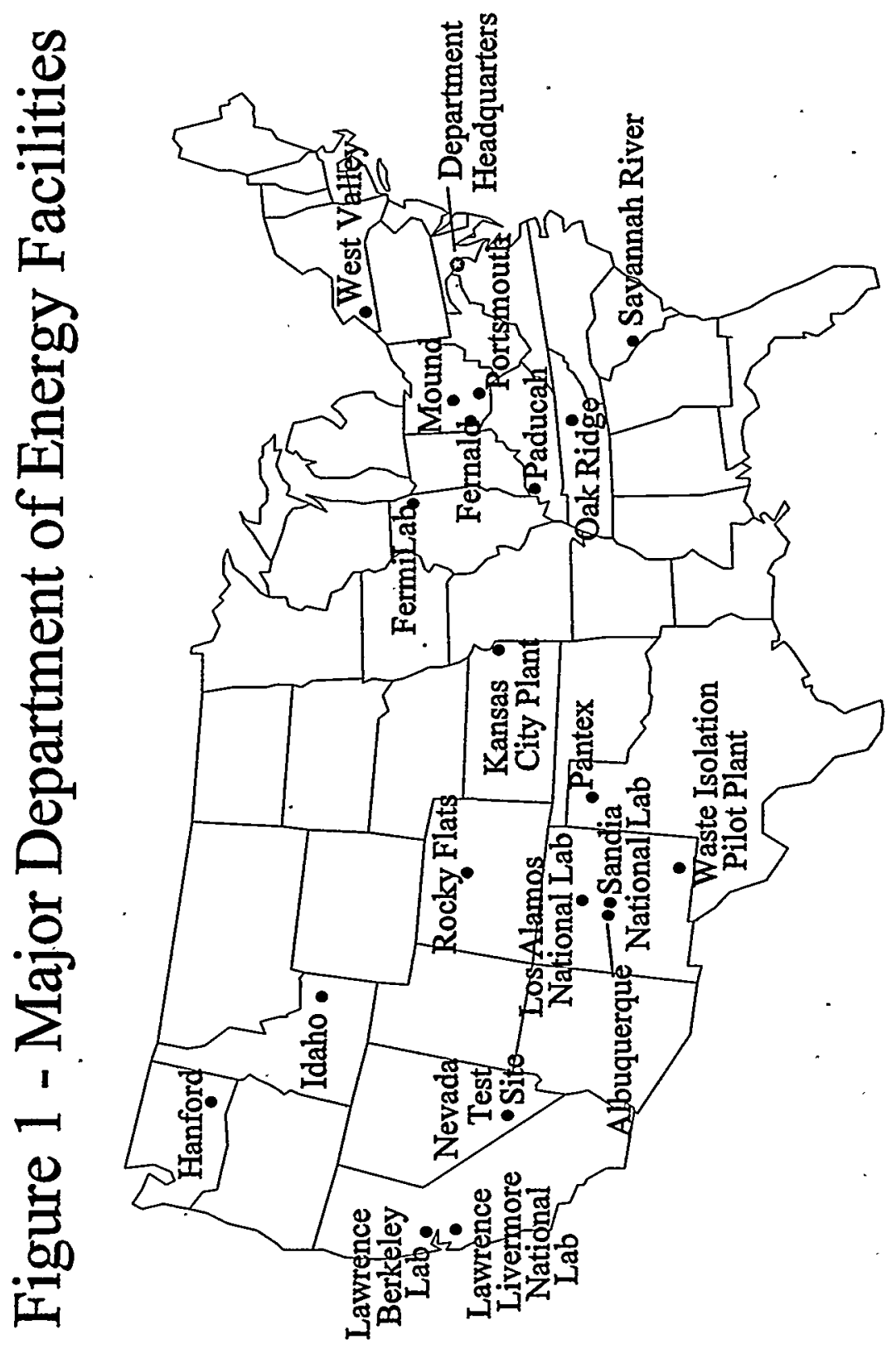


Table 1.B - Summary Status of Board Recommendations

\begin{tabular}{|c|c|c|c|}
\hline REC & SUBJECT & OPEN & CLOSED \\
\hline $90-1$ & Savannah River Operator Training & & $10 / 27 / 92$ \\
\hline $90-2$ & Codes and Standards & & $10 / 24 / 95$ \\
\hline $90-3$ & Hanford Waste Tanks & & $5 / 1 / 92$ \\
\hline $90-4$ & Rocky Flats Operational Readiness Reviews & & $2 / 16 / 95$ \\
\hline $90-5$ & Systematic Evaluation Plans & & $10 / 24 / 95$ \\
\hline $90-6$ & Rocky Flats, Plutonium in the Ventilation Ducts & & $10 / 24 / 95$ \\
\hline $90-7$ & Hanford Waste Tanks - Ferrocyanide Safety Issue & & $9 / 4 / 96$ \\
\hline $91-1$ & Safety Standards Program & & $10 / 27 / 92$ \\
\hline $91-2$ & Reactor Operations Management Plan at Savannah River & & $10 / 27 / 92$ \\
\hline $91-3$ & Waste Isolation Pilot Plant & & $10 / 27 / 92$ \\
\hline $91-4$ & Rocky Flats, Building 559 Operational Readiness Review & & $5 / 1 / 92$ \\
\hline $91-5$ & Savannah River K Reactor Power Limits & & $4 / 7 / 93$ \\
\hline $91-6$ & Radiation Protection & & $11 / 8 / 96$ \\
\hline $92-1$ & Operational Readiness of the HB-Line at Savannah River & & $10 / 27 / 92$ \\
\hline $92-2$ & Facility Representatives & & $9 / 17 / 96$ \\
\hline $92-3$ & HB-Line Operational Readiness Reviews at Savannah River & & $2 / 3 / 93$ \\
\hline $92-4$ & Multi-Function Waste Tank Facility at Hanford & $\mathrm{X}$ & \\
\hline $92-5$ & Discipline of Operations & & $10 / 24 / 95$ \\
\hline $92-6$ & Operational Readiness Reviews & & $10 / 24 / 95$ \\
\hline $92-7$ & Training and Qualification & & $11 / 4 / 93$ \\
\hline $93-1$ & Standards Utilization in Defense Nuclear Facilities & & $3 / 25 / 99$ \\
\hline 93-2 & Critical Experiments Capability & & $12 / 30 / 97$ \\
\hline $93-3$ & Improving Technical Capability & & $11 / 9 / 99$ \\
\hline $93-4$ & Environmental Restoration Management Contracts & & $6 / 28 / 96$ \\
\hline $93-5$ & Hanford Waste Tanks Characterization Studies & & $11 / 15 / 99$ \\
\hline $93-6$ & Nuclear Weapons Expertise & & $4 / 27 / 99$ \\
\hline $94-1$ & Improved Schedule for Remediation & $\mathrm{x}$ & \\
\hline $94-2$ & Safety Standards for Low Level Waste & & $12 / 22 / 99$ \\
\hline $94-3$ & Rocky Flats Seismic and Systems Safety & & $5 / 27 / 99$ \\
\hline $94-4$ & Deficiencies in Criticality Safety at Oak Ridge Y-12 & & $3 / 12 / 99$ \\
\hline $94-5$ & Rules, Orders, and Other Requirements & & $6 / 10 / 99$ \\
\hline $95-1$ & Improved Safety of Cylinders Containing Depleted Uranium & & $12 / 16 / 99$ \\
\hline $95-2$ & Safety Management & $\underline{x}$ & \\
\hline $96-1$ & In-Tank Precipitation System at Savannah River & $\mathrm{X}$ & \\
\hline $97-1$ & Safe Storage of Uranium-233 & $\mathrm{X}$ & \\
\hline $97-2$ & Criticality Safety & $\mathrm{X}$ & \\
\hline $98-1$ & Resolution of Internal Oversight Finding & $\mathrm{X}$ & \\
\hline $98-2$ & Safety Management at the Pantex Plant & $\mathrm{X}$ & \\
\hline $99-1$ & Safe Storage of Pits at the Pantex Plant & $\mathrm{X}$ & \\
\hline $2000-1$ & Stabilization and Storage of Nuclear Material & $\mathrm{X}$ & \\
\hline $2000-2$ & Configuration Management, Vital Safety Systems & $\mathrm{X}$ & \\
\hline
\end{tabular}


Table 1.C - Key Dates For Active Board Recommendations

\begin{tabular}{||l|l|c|c|c||}
\hline REC & \multicolumn{1}{|c|}{ SUBJECT } & $\begin{array}{c}\text { REC } \\
\text { DATE }\end{array}$ & $\begin{array}{c}\text { RESPONSE } \\
\text { DATE }\end{array}$ & $\begin{array}{c}\text { IMPL } \\
\text { PLAN } \\
\text { DATE }\end{array}$ \\
\hline $92-4$ & Multi-Function Waste Tank Facility at Hanford & $7 / 6 / 92$ & $8 / 28 / 92$ & $\begin{array}{c}10 / 8 / 97 \\
\text { (Revision } 2)\end{array}$ \\
\hline $94-1$ & Improved Schedule for Remediation & $5 / 26 / 94$ & $8 / 31 / 94$ & $\begin{array}{c}6 / 8 / 00 \\
\text { Revision } 3 \text { ) }\end{array}$ \\
\hline $95-2$ & Safety Management & $10 / 11 / 95$ & $1 / 18 / 96$ & $4 / 18 / 96$ \\
\hline $96-1$ & In-Tank Precipitation System at Savannah River & $8 / 14 / 96$ & $9 / 16 / 96$ & $11 / 12 / 96$ \\
\hline $97-1$ & Safe Storage of Uranium-233 & $3 / 3 / 97$ & $4 / 25 / 97$ & $9 / 29 / 97$ \\
\hline $97-2$ & Criticality Safety & $5 / 19 / 97$ & $7 / 14 / 97$ & $12 / 12 / 97$ \\
\hline $98-1$ & Resolution of Internal Oversight Findings & $9 / 28 / 98$ & $11 / 20 / 98$ & $3 / 10 / 99$ \\
\hline $98-2$ & Safety Management at the Pantex Plant & $9 / 30 / 98$ & $11 / 20 / 98$ & $\begin{array}{c}9 / 25 / 00 \\
(\text { Revision } 1)\end{array}$ \\
\hline $99-1$ & Safe Storage of Pits at the Pantex Plant & $8 / 11 / 99$ & $10 / 12 / 99$ & $2 / 1 / 00$ \\
\hline $2000-1$ & Stabilization and Storage of Nuclear Material & $1 / 14 / 00$ & $3 / 13 / 00$ & $6 / 8 / 00$ \\
\hline $2000-2$ & Configuration Management, Vital Safety Systems & $3 / 8 / 00$ & $4 / 28 / 00$ & $10 / 31 / 00$ \\
\hline
\end{tabular}




\section{KEY DEPARTMENT SAFETY INITIATIVES}

Each of the key initiatives described below involves significant changes from past operating practices. They involve systems-based solutions, cross-organizational/site integration, cross-program integration, and fundamental management culture changes to address underlying safety and management issues. For example, Department determinations about ultimate pathways and long-term dispositions for hazardous materials require deliberate study and integration across the defense nuclear facilities complex. Funding and management of Department-wide efforts to maintain strong criticality prediction and control capabilities requires cross-program coordination. The ongoing transition from expert-based safety management to requirements-based safety management systems continues to be a significant cultural adjustment that needs to be achieved in all organizational parts and levels. The transition requires changes to practices developed over many years by sites, facilities, programs, and organizations operating largely independently and autonomously. Nevertheless, the Department is making progress overcoming these difficult challenges to establish a safety culture that is systems-based, requirements-based, and integrated across programs, organizations, and facilities.

\section{A. Operational Readiness of Vital Safety Systems}

A key safety initiative for 2000 was the development of a plan that evaluates the condition of defense nuclear facility vital safety systems which protect the public, facility workers and the environment. The plan also takes action to enhance safety system operability measures. The plan was developed in response to Board Recommendation 2000-2 and will take several years to implement fully.

On March 8, 2000, the Board issued Recommendation 2000-2, concerning potentially degrading conditions of vital safety systems and the capability to apply engineering expertise to maintain the configuration of these systems. Specifically, the recommendation identified possible degradation in confinement ventilation systems and noted that the Department has not adopted the nuclear business' long-standing practice of designating system engineers for systems and processes that are vital to safety. The Board recommended that the Department take action to (1) assess the condition of its confinement ventilation systems, (2) develop programs that strengthen safety. system expertise of contractor and federal technical personnel, and (3) improve the selfassessment processes that evaluate the condition of vital safety systems. On April 28, 2000, the Department accepted the Board's Recommendation, and in a September 8, 2000. letter, the Board amplified the intent of Recommendation 2000-2. 
In developing a 2000-2 implementation plan, the Department identified additional practices that enhance the ability to apply engineering expertise to maintain and operate vital safety systems that protect the public, worker and the environment. The purpose of the Department's plan is to address a near-term objective of completing an initial assessment of the operational readiness of vital safety systems. Actions to correct and/or compensate for degradation will be identified and prioritized to ensure that these systems remain in, or are restored to, their operational readiness condition. As a longterm objective, the Department will institutionalize a process that ensures continued operational readiness of vital safety systems and supports the Department's continuing effort to establish Integrated Safety Management (ISM) as the central, enduring framework for safely accomplishing the Department's mission and work.

\section{Safety System Assessments}

Prior to issuing the 2000-2 Implementation Plan, the Secretary of Energy initiated action to assess the abilities of DOE sites to effectively prevent fires and respond effectively in the event a fire occurs. Beginning with an initial review of current capabilities related to wildfire safety, the Department will assess aspects of emergency management that deal with the ability to respond to a wildfire. Using data obtained from the initial review, the Department will conduct a comprehensive study that will provide an in-depth evaluation of the capability to respond to wildfires and will emphasize facility fire safety, including fire detection and suppression systems and facility-specific programs that support those systems.

The 2000-2 Implementation Plan activities will employ a two-phased approach to verify the operational readiness of vital safety systems. During the Phase I, operating contractors, overseen by federal field office personnel, will perform an initial assessment of vital safety system operational readiness. To accomplish this, these contractors will use a set of criteria to identify vital safety systems; review existing operational and maintenance records; and qualitatively determine a readiness state for each vital safety system within defense nuclear facilities.

Once Phase I assessments are complete, the Department will evaluate the results and identify key facilities and/or systems (e.g., ventilation systems) where issues or concerns are identified regarding the operational readiness of vital safety systems. The Department will then further assess these key facilities and/or systems in Phase II, while existing self-assessment processes will continue to be relied upon to maintain the condition of the remaining facilities. 
The Department also will track deficiencies and associated corrective actions/compensatory actions that arise from Phase I and Phase II assessments and will manage them in local corrective action management systems.

\section{System Expertise}

The nuclear industry has a long-standing practice of designating personnel with expertise (i.e. system engineers) for systems and processes that are vital to safety. In response to Board Recommendation 2000-2, the Department performed a review of system engineer programs and configuration management practices in place at commercial and DOE facilities. Although the Department's contractors have programs for maintaining configuration control of safety systems, the implementation plan has identified additional actions that institutionalize a consistent set of requirements related to the application of a system engineer concept in maintaining configuration control of vital safety systems at defense nuclear facilities.

The oversight role of the DOE Federal workforce requires familiarity with vital safety systems and the contractor's application of the system engineer concept. Once contractors implement a system engineer program, the Department needs to ensure that Federal technical personnel knowledgeable of those safety systems are available to support the contractor's life-cycle management of vital safety systems, particularly when significant system problems arise. In 2001, the Department will assess the availability and sufficiency of DOE Federal expertise and recommend actions necessary to ensure that this expertise can support the life-cycle management of vital systems.

\section{$\underline{\text { Self-Assessment Reviews }}$}

The Department and its contractors have many oversight and feedback mechanisms to improve operations throughout the DOE complex. In developing the ISM System, the Department established the guiding principle that line management is responsible for safety. It is the line managers' duty to get personally involved in reviewing and using performance feedback information to drive continuous improvement. To provide senior leadership with the information obtained from these oversight and feedback processes, the Department will begin a regular practice of periodically reviewing ES\&H assessments and summarizing the assessment results for the Secretary. This review will improve the feedback process and will focus management attention on issues. 


\section{B. Stabilization of Excess Nuclear Materials}

In February 1995, the Department established a program and plan for expediting remediation and stabilization of excess nuclear materials into safe, stable states for interim and long-term storage pending ultimate disposition. The halt in materials production for nuclear weapons froze the manufacturing pipeline in an intermediate state that was not optimal for long-term storage. Specifically, certain liquids and solids containing fissile materials and other radioactive substances - i.e., substances located in spent fuel storage pools, reactor basins, reprocessing canyons, and various other facilities once used for processing and weapons manufacture - needed to be stabilized.

Stabilization efforts were grouped by material types to take advantage of synergies. Six major categories of excess nuclear materials were identified: plutonium solutions, plutonium metals and oxides, plutonium residues and mixed oxides, special isotopes, certain uranium, and spent nuclear fuel. To date, the majority of high risk materials have in fact been stabilized, specifically:

- All known plutonium metal in direct contact with plastic has been repackaged.

- The largest volumes of plutonium solutions have been stabilized.

- $\quad$ Significant progress has been achieved in stabilizing high risk spent fuel and building spent fuel storage facilities.

As the Department continues to pursue the remaining high risk material stabilization activities, it is also focusing on managing the stabilization of more difficult, diverse material groups, such as plutonium residues.

The Nucleár Materials Stabilization Task Group, established in February 1995 and incorporated into the Office of Nuclear Materials and Spent Fuel in November 1999, integrates the Department's programs for stabilizing excess nuclear material to achieve safe, stable states for interim and long-term storage pending ultimate disposition. This office has established an integrated, complex-wide program for managing nuclear materials stabilization activities. To date, stabilization activities have been addressed complex-wide in the following areas:

- developing integrated Department-wide approaches to stabilization issues;

- $\quad$ evaluating facility stabilization capabilities; 
- $\quad$ preparing facilities to support.spent fuel and nuclear material removal and consolidation for long term storage; and

- procuring standardized equipment to support plutonium oxide stabilization and packaging for long-term storage.

The Board issued Recommendation 2000-1 on January 14, 2000, reiterating the urgency of completing the nuclear material stabilization activities which had already been committed to under implementation plan for Recommendation-94-1. The Department continues to share the Board's concerns regarding nuclear materials stabilization. The urgent safety issues described in the original recommendation have either been corrected or had compensatory measures put in place to protect workers and the public until stabilization can be completed. Accordingly, with the approval and delivery of the 2000-1 implementation plan in June 2000, the Secretary proposed closure of Recommendation 94-1 to the Board as the remaining stabilization activities are being pursued under Recommendation 2000-1.

Also during 2000, the Department completed a re-evaluation of its plans for storage of excess weapons-useable plutonium awaiting disposition. The modifications to the Department's nuclear materials stabilization plans arising from this re-evaluation included cancellation of the Actinide Packaging and Storage Facility at Savannah River Site and a re-baselining of the Savannah River Site stabilization schedule. These were reflected in the June 2000 implementation plan.

At the time that the June 2000 plan was issued, the Office of Defense Programs outlined a process which they would follow in preparing an integrated plan with milestones for either stabilizing or discarding the remaining Recommendation 94-1 materials at Los Alamos National Laboratory. Revision 1 of the 2000-1 implementation plan was approved by the Secretary in January 2001.

\section{Nuclear Safety Rule}

On October 10, 2000, the Department issued an Interim Final Rule on Nuclear Safety Management as 10 CFR Part 830 (65 FR 60291). Comments were requested by November 9, 2000, and the Interim Final Rule became effective on December 11, 2000. The Department reviewed the comments provided on the Interim Final Rule and issued a notice in the January 2001 Federal Register that responded to the significant comments, and makes minor changes to the rule in response to the comments. The Final Rule became effective on February 9, 2001. Completion of this 
rule is a substantial upgrade to the formalization of the Department's safety infrastructure.

The rule represents the culmination of a lengthy phase of safety rule making that began with a notice of proposed rule-making in 1991. The original notice envisioned nine safety management topics. The rule for the first topic, quality assurance, was issued in 1994. The Final Rule revised the scope of the rule, added requirements to the quality assurance topic consistent with safety management, and added requirements for safety bases. With the issuance of this Final Rule, the Department considers that the nine nuclear safety management topics originally proposed in the 1991 Notice are adequately covered through the combination of the Part 830 rule and contract requirements.

Substantive changes to Part 830 as a result of this rule-making are summarized as follows:

- The scope of the rule was expanded to govern the conduct of DOE contractors, DOE personnel, and other persons conducting activities (including providing services and items) that affect or may affect, the safety of DOE nuclear facilities, including subcontractors and suppliers.

- A provision was added to the quality assurance rule [Part 830, Subpart A] requiring integration of quality assurance with the Safety Management Systems, developed in accordance with Department of Energy Acquisition Regulation 48 CFR 970.5204-2 (now 970.5223-1), Integration of Environment, Safety, and Health into Work Planning and Execution.

- A provision was added to the quality assurance rule [Part 830, Subpart A] requiring for contractors to identify and document voluntary consensus standards they relied upon to develop and implement their Quality Assurance Plans.

- The work process provision of the quality assurance rule [Part 830; Subpart A] was clarified to broadly require work to be performed consistent with standards and controls adopted to meet regulatory and contract requirements that may affect nuclear safety.

- A new Subpart B was added to delineate provisions for nuclear facility safety bases, as summarized further below.

The new Subpart B provides the following top-level requirements for contractors of DOE hazard category 1,2 , and 3 nuclear facilities: 
- Contractors must perform work in accordance with established safety basis and, in particular, with the hazard controls that ensure adequate protection of workers, the public, and the environment.

- Contractors must establish and maintain a safety basis with a documented safety analysis, including annual submittal of updated documented safety analysis or a letter stating that no changes have occurred.

- Contractors must establish and implement an Unreviewed Safety Question (USQ) process that includes an annual submittal of a summary of USQ determinations performed.

- Contractors must derive technical safety requirements from the documented safety analysis.

All contractors are required to perform work in accordance with the safety basis in effect on October 10,2000. For facilities with safety basis in compliance with the new rule, contractors must notify DOE by April 9,2001, documenting the adequacy of the existing safety basis and requesting DOE to issue a safety evaluation report that approves the existing safety basis. Other existing contractors - those who do not have adequate existing safety basis for their facilities - must provide their safety basis for DOE approval by April 10,2003. Contractors for new facilities may not begin operations or modifications without compliance with this rule.

While many of the safety basis provisions of Subpart B to Part 830 have been in effect for many years through the DOE order system, adding the safety basis requirements to Part 830 improves the clarity and consistency of these requirements and enhances the Department's ability to enforce the safety basis requirements through the PriceAnderson Amendments Act provisions.

\section{Establishment of the National Nuclear Security Administration}

On March 1, 2000, the National Nuclear Security Administration (NNSA) began operations, as established by the National Defense Authorization Act for Fiscal Year 2000 , Public Law 106-65. The mission of the NNSA is to carry out the national nuclear security responsibilities of the Department of Energy, including: (1) maintenance of a safe, secure and reliable stockpile of nuclear weapons and associated materials capabilities and technologies; (2) promotion of international nuclear safety and nonproliferation; and (3) administration and management of the naval nuclear propulsion program. 
The NNSA is a semi-autonomous organization within the Department, led by the Under Secretary and Administrator of NNSA. General John Gordon was sworn in as the first Administrator on July 12, 2000. Three program offices report to the Administrator: (1) the Office of the Deputy Administrator for Defense Programs, (2) the Office of the Deputy Administrator for Defense Nuclear Nonproliferation, and (3) the Office of the Deputy Administrator for Naval Reactors. In addition, the following support offices report to the Administrator: (1) Office of the Administrator, (2) General Counsel of the Administration, (3) Office of Defense Nuclear Counterintelligence, and (4) Office of Defense Nuclear Security. The Department's Office of Emergency Operations was transferred to the NNSA in December 2000.

Substantial DOE expertise on worker health and safety and environmental protection resides in other program and support offices that are not within the NNSA. The Implementation Plan for the NNSA ensures that this expertise, and the capability to provide independent oversight and reviews, remains available to NNSA programs. The NNSA continues to coordinate with other DOE programs on a number of key Boardrelated issues, such as integrated safety management and clean-up and disposition of hazardous wastes.

\section{E. Criticality Safety}

Criticality safety is protection from the consequences of a criticality accident, preferably by accident prevention. Criticality safety encompasses procedures, training, and other precautions, in addition to physical protection. Where operations involve significant quantities of fissile material, accidental criticality is a hazard for which analysis must be performed and controls must be identified and implemented. The Department recognizes that identifying and analyzing credible accident scenarios and implementing appropriate controls to prevent or mitigate an accidental criticality must involve an efficient process that does not use excessive resources and that allows work to be safely accomplished in a timely manner.

The Department's ongoing criticality safety activities were initiated under the Nuclear Criticality Predictability Program (commenced in 1996) and are now subsumed under the implementation plan for Board Recommendation 97-2. The Department's Nuclear Criticality Safety Program establishes an infrastructure to address nuclear criticality needs. The program consists of seven elements: nuclear data, analytical methods, experiments, benchmarking, training, nuclear criticality information preservation and dissemination, and extending applicable ranges of bounding curves and data. These elements preserve criticality experiment capabilities and provide data and numerical 
methods vital to current and future Departmental missions. The Nuclear Criticality Safety Program five-year plan describes these elements in detail.

The Department continued implementing a criticality safety self-improvement initiative which was begun in the Spring of 1999. Activities during calendar year 2000 included:

- Reviews of operational criticality safety controls at five key Department facilities were completed and the results were forwarded to Secretary Richardson.

- Self-assessments for all facilities and operations involving fissile material were completed. The Office of Environment, Safety and Health has completed its review of these self-assessments and will provide results to the Secretary in early 2001.

- The Department began studies aimed at relocation of the Los Alamos Critical Experiments Facility to assure preservation of this important capability.

In September 2000, the Deputy Secretary directed a continuation of the criticality safety initiatives through implementation of several additional actions, which are ongoing. These additional actions included:

- Sites were charged with developing corrective action plans for issues identified in criticality safety self-assessments and to develop criticality safety program improvement plans.

- The Office of Environment, Safety, and Health was charged with conducting follow-up assessments of the five key facilities to evaluate the effectiveness of implemented corrective actions. These reviews are scheduled to be conducted - in the first half of 2001.

- Field elements were charged with completing incorporation of performance metrics into contracts, within the scope of Integrated Safety Management activities.

- The Federal Technical Capabilities Panel was charged with determining where shortages of criticality safety personnel exist and where expected shortages could occur within the next three years. Field Elements were charged with correcting any identified shortages. 
- $\quad$ The commitment in the Department's implementation plan for recommendation 97-2 to qualify Federal staff by December 31, 2000 was reiterated to Field Elements. Field Elements were also charged with assuring that contractors develop criticality safety qualification programs according to guidance and requirements published in page change 3 to DOE O 420.1, Facility Safety.

- $\quad$ The Nuclear Criticality Safety Program Management Team was charged with conducting a workshop involving facility management and criticality safety staff to improve the integration of criticality safety into operations. The workshop was conducted in October 2000.

The:Department will continue to follow up on these activities with a view towards continuous improvement of its operational criticality safety programs.

\section{F. Integrated Safety Management}

\section{Initial Implementation}

In October 1999, the Deputy Secretary established a requirement that each field and program office report to him on the completion of the initial implementation of the Department's ISM program by the Secretary's target date of September 2000. In December 1999, the first of twelve major field offices, Savannah River Operations Office, reported completion of initial implementation. During the ensuing months through September 2000, nine additional field office managers and all but one of the headquarters program offices reported that all of the facilities and activities under them had completed their initial implementation of ISM.

Oak Ridge's Y-12 Plant, Los Alamos National Laboratory's (LANL) Chemical Metallurgical Research (CMR) Building, and LANL's TA-55 facility did not achieve the Secretary's target date for implementation. The New Mexico Cerro Grande fire significantly impacted LANL's ability to conduct its ISM verifications by the target date. A Phase II ISM verification was conducted at the Y-12 Plant in August 2000, but the contractor was determined to have gaps in its ISM implementation. In addition, the Nevada Field Manager reported that the Nevada Test Site had substantially implemented an effective ISM system, but that additional focus was needed on refining the site's feedback and improvement and training programs, as well as the Bechtel Nevada Company's work control process. The associated facilities will undergo Phase II ISM verifications that are scheduled to be completed by May 2001. 
- In reporting initial ISM implementation, each field element and program office manager certified that the following seven criteria, established by the Deputy Secretary in his October 1999 memorandum, had been met satisfactorily:

1. Department and contractor organizations had established and were maintaining agreed-upon sets of applicable requirements and standards.

2. The Department had approved applicable Safety Management System Descriptions.

3. The Department had verified adequate implementation of applicable Safety Management Systems.

4. Department Functions, Responsibilities and Authorities (FRA) Documents were implemented.

5. The Department had verified that feedback and improvement programs were in place and effective.

6. The Department's line oversight programs were in place and effective.

7. The Department had established a documented process to maintain applicable Safety Management Systems.

\section{Field Implementation Activities}

Highlights of safety management implementation activities in 2000 are summarized below by the responsible Operations or Field Office for these and other facilities across the Department's defense nuclear facilities complex.

\section{Environmental Management}

Savannah River Operations Office (DOE-SR). The Integrated Safety Management System (ISMS) at SRS continues to be a strength in all aspects of the life cycle of facilities and activities. This life cycle application is exemplified in project management with the Tritium Extraction Facility Project at the Savannah River Technology Center, with a strong Conduct of Research and Development discipline through all canyon and waste management operations, and with environmental restoration and decontamination and deactivation activities. Implementing mechanisms of ISMS are being maintained and continuously improved to support exemplary 
performance. The Westinghouse Savannah River Company (WSRC) ISM Executive Steering Committee provides the focal point for this maintenance through their senior management commitment to and leadership of ISMS implementation. This committee, which includes representation from the entire spectrum of SRS facilities and activities, revised the ISM Strategic Plan and corresponding implementing actions for 2000 and beyond. The WSRC independent oversight function continues to regularly conduct ISM evaluations of performance in facilities and programs, with periodic oversight by DOE-SR. An area of strength in the WSRC implementation is enhanced worker involvement in planning, execution, and feedback and improvement of safe work activities. This strength derives from a validated Voluntary Protection Program, an aggressive behavior-based safety approach, and a "Front Line Voices on Safety" Team, which provides an effective avenue for raising issues to the attention of senior management. SRS commissioned an in-depth evaluation of assessment, oversight, and management evaluation processes through an assist visit conducted by the Institute for Nuclear Power Operations (INPO). As a result of this visit, WSRC and DOE-SR are pursuing corrective action plans to address the opportunities for improvement identified by INPO. Standards requirements, ISMS Description documents, and authorization agreements continue to be routinely reviewed and updated to maintain a current posture.

Idaho Operations Office (DOE-ID). The ID methodology for determining ISM implementation was two-fold: (a) complete Phase I and Phase II verifications for all INEEL facilities; and (b) have both the INEEL management and operations contractor (BBWI) and DOE-ID step back and self-assess their organizations' ISM implementation in light of the results of Phase I and Phase II verification reports and against the seven criteria of the Deputy Secretary's October 25, 1999, memorandum.

The INEEL completed a Phase I verification and three separate Phase II ISM Verifications covering all INEEL contractor operated facilities and functional areas, in accordance with the guidance provided in the Integrated Safety Management Systems Verification Team Leader's Handbook and the Integrated Safety Management System Guide. In addition, a separate Phase I and Phase II verification was conducted at the DOE-owned and -operated Radiological and Environmental Sciences Laboratory. After the final INEEL Phase II verification, BBWI conducted a self-assessment of their ISM implementation against the seven criteria of the Deputy Secretary's October 25, 1999 memorandum, and formally declared to the Idaho Manager that ISM is implemented at the INEEL. Concurrent with BBWI'S self-assessment, all DOE-ID Assistant Managers conducted self-assessments of their organizations' ISM implementation against the Deputy Secretary's October 25, 1999 memorandum; the five core functions and eight guiding principles of the INEEL ISMS; and the DOE-ID SMS Description Document. 
Based on these self-assessments, all DOE-ID Assistant Managers declared to the ID Manager that ISM was implemented in their respective organizations.

The Department reviewed Revision 4 of the Program Description Document for the INEEL Integrated Safety Management System (PDD-1004) and approved it on February 18,2000 . This revision reflected organizational, process and document changes resulting from the $\mathrm{M} \& \mathrm{O}$ contract transition.

To summarize actions over the last several years, the INEEL has aggressively developed a rigorous Integrated Safety Management System. A significant aspect of this system is the continuous monitoring of ISM implementation through line oversight and independent assessment to identify areas for improvement, using the feedback and improvement mechanisms implemented by both DOE-ID and contractor organizations. ISM will be systematically evaluated, and issues that may arise will be addressed with the full support and involvement of site management, and with worker input. While ID believes that an effective and functional Integrated Safety Management System is in place at the INEEL, management has recognized that the "health" of ISM requires nurturing and changes, while continuing to make progress toward the goal of continuous improvement. The INEEL is dedicated to maintaining a safe work environment for all INEEL workers and to performing work safely.

Oak Ridge Operations Office (DOE-OR). DOE-OR and NNSA Y-12 have twelve major, prime contracts into which the ISM DEAR clause has been incorporated. All of its prime contractors, except Wackenhut Services, Inc., which recently was awarded a contract for protective services, have DOE-approved SMS descriptions. Ten ISM verifications were completed during 2000.

Overall, Oak Ridge Operations (DOE-OR) and its contractors have made substantial progress in establishing robust and effective Integrated Safety Management Systems (ISMS). Nine of the twelve Oak Ridge contractors have completed Phase II verifications. Lockheed Martin Energy Systems, Inc. (Y-12 Plant contractor) did not meet all of the objectives in the latest verification of its program. Specifically, the verification team stated that the program required improvement in Balance of Plant operations (non-nuclear facilities) and in feedback and improvement processes. The new contractor, BWXT Y-12, LLC, has established March 31, 2001, as the date by which actions necessary to complete its ISMS implementation will be completed. Foster-Wheeler Engineering Corporation conducted a Phase I verification of the design stage of a future plant satisfactorily, and East Tennessee Materials and Energy Corporation conducted a Phase I verification satisfactorily and is awaiting a Phase II verification as soon as work can be conducted. In all of the ISM verifications 
conducted during 2000, some opportunities for improvement were identified. In the verification of Bechtel-Jacobs Co. (BJC), insufficient maturity was identified as a weakness in some aspects of program implementation. BJC has taken appropriate compensatory actions and is implementing a corrective action plan for continuous improvement. Wackenhut Services, Inc., the new security contractor, will undergo a combined Phase I and II ISMS verification in February 2001.

As part of a continuing feedback and improvement process for ISM, DOE-OR conducted a forum on December 1, 2000, for DOE-OR managers, division directors, supervisors, Facility Representatives, ES\&H subject matter experts, and program/project Managers. At the forum, the DOE-OR Manager covered the latest status of ISM verifications, the expectations for the ISM programs, and the path forward of ISM for DOE-OR and its contractors. Each Assistant Manager organization addressed the status of their contractor(s), ISM program, and expectations. The forum included an open discussion between the managers and the audience concerning expectations and shortcomings of contractor operations.

Ohio Field Office (DOE-OH). The Ohio Field Office has implemented a robust and effective Integrated Safety Management System during FY2000. Local policies and procedures require routine evaluation and an active issues management program. A key attribute of this system is the identification of concerns and opportunities for improvements, development and management of corrective actions, verification of corrective action closure, and communication of lessons learned. The Ohio Field Office has effectively and uniformly embedded ISM into the local DOE and contractor site documents and work processes. Additional opportunities for improvement exist and are actively sought out by all levels of the support and line management federal and contractor staff in support of the Ohio Field Office's commitment to continuous improvement. The Ohio Field Office continues to place additional emphasis on visible and active management support for safety management system implementation while continuing on a path to closure.

The Miamisburg Environmental Management Project (MEMP) Phase II ISM verification was successfully completed in May 2000 . With sustained management commitment in safety management, MEMP continues to provide strong leadership and direction for ISM implementation, as evidenced by the site achieving 4 million safe hours in August 2000 without a lost day away from work due to an injury. Continuous emphasis in ensuring ISM implementation will be monitored through quarterly performance indicators, and by conducting a reverification of ISM implementation effectiveness during the summer of 2001 . 
In November 1999, a U.S. Department of Energy Voluntary Protection Program (VPP) review team conducted an on-site evaluation of West Valley Nuclear Services Company (WVNS) health and safety program recommending that WVNS be accepted into the DOE-VPP at the Star level. WVDP completed its first ISMS annual review in February 2000. No deficiencies were identified during the review and the team reported that ISMS continues to be effectively implemented at the WVDP. In August 2000 , the WVDP achieved one million hours worked without a lost workday injury, providing further evidence of the site's safety commitment.

For the Fernald Environmental Management Project, the Ohio Field Office Manager confirmed ISMS verification on January 26,2000. This confirmation was based upon Phase I and Phase II ISMS reviews that were conducted in November and December 1999 respectively. Several positive outcomes resulting from implementation of ISMS at the Fernald site include enhanced worker feedback, improved safety performance, and successful project performance. Following ISMS implementation, the Fluor Fernald, Inc., submitted a VPP application in August 2000. The subsequent review. conducted in October 2000 identified a number of strengths and no significant weaknesses. It is anticipated the Fernald site will receive VPP recognition in December 2000. The annual ISMS assessment at Fernald is scheduled to be completed by March 31,2001 . This assessment is expected to verify that ISMS has been successfully transitioned under the new closure contract.

Office of River Protection (ORP). The Office of River Protection declared ISMS implemented in July 2000 and is taking aggressive steps to improve implementation. An Implementation Management Assessment was conducted in May 2000 to ensure that a smooth transition had occurred when Lockheed Martin Hanford Company (LMHC) became a prime contractor to ORP in October 1999, and that a smooth transition took place when $\mathrm{CH} 2 \mathrm{M}$ Hill Hanford Group obtained the contract in December 1999. ORP has also conducted assessments of the contractor's DOE Policy 450.5-driven self-assessment program, as well as its corrective action management and "Lessons Learned" programs.

ORP has seen improvements in safety performance at the Hanford tank farms as a result of ISM implementation. For example, procedural compliance has become more rigorous and ingrained, and worker involvement in work planning has become the routine. Management's presence in the tank farms has increased markedly because of the contractor's establishment of a disciplined Management Observation Program.

ORP's Master Assessment Plan for FY 2001 includes quarterly reviews of ISM implementation, where a core function is selected, the contractor's Safety Management 
System description relating to that core function is reviewed, and field implementation is verified. In addition, an annual ISMS review is scheduled for May 2001. The first Safety System Functional Inspection is scheduled for February 2001, during which every aspect of a major tank farm safety system will be thoroughly scrutinized.

Richland Operations Office (DOE-RL). During 2000, ISM verifications were conducted for Fluor Hanford, Inc. (FHI), and Bechtel Hanford, Inc. (BHI). Authorization Agreements were prepared and approved for the 200 Area Burial Grounds, Central Waste Complex, Waste Receiving and Packaging Facility, 242-A Evaporator, Fast Flux Test Facility, Plutonium Uranium Extraction Facility (Tunnels), 224-T (formerly Transuranic Waste Storage and Assay Facility), 324 Facility, 327 Facility, B-Plant Facility, and the 233-S Plutonium Concentration Facility Decommissioning Project. Authorization Agreements approved prior to FY 2000 were maintained and periodically updated, as required.

To reflect FHI's new single-company, project-focused organization, a revision to the ISM System Description was issued. DOE-RL conducted a Phase I Verification of the remaining FHI scope in April 2000. The FHI ISM System Description was responsive to the DEAR clauses and DOE management direction, but the team identified weaknesses that needed to be corrected prior to its approval. Following validation of corrective actions, DOE-RL approved the ISM System Description. An FHI Phase II verification was then conducted in June/July 2000. This ISMS verification evaluated FHI and the following project management areas: Analytical Services Provider, Fast Flux Test Facility, the Nuclear Material Stabilization Project, the River Corridor Project, and the Waste Management Project. Following validation of corrective actions, DOE-RL determined in August 2000 that the FHI 's ISMS had been satisfactorily implemented.

DOE-RL also conducted a combined Phase I and II ISMS verification of Bechtel Hanford in March 2000 and approved the BHI ISM System Description in May 2000. The follow-on Phase II verification determined that ISMS was adequately implemented within the BHI Environmental Restoration Contract work processes. The Phase II verification identified several concerns associated with five summary-level opportunities for improvement and BHI developed and completed an action plan that satisfactorily addressed the identified concerns.

ISMS verifications identified the Automated Job Hazards Analysis, an institutionalized job hazards analysis tool, as a noteworthy mechanism that ensures worker involvement and supervisory/management engagement in work planning and hazard analysis process. ISM continues to be a key driver for accelerating the implementation of 
several of safety-related initiatives, such as Enhanced Work Planning, Voluntary Protection Program, ISO 14001, etc., at the Hanford Site. The ISM Verifications also identified that workers and senior management were committed to Integrated Safety Management and "Doing Work Safely." This commitment was evidenced by the significant number of hours worked at Hanford without a lost workday.

The Hanford Site hosted a national ISM Lessons Learned Workshop in December 2000. The workshop was attended by federal personnel, contractor managers, workers, Environment, Safety, Health, and Quality (ESH\&Q) professionals, and Hanford stakeholders. This workshop served as an excellent participation and education tool. Stakeholder representatives from the Hanford Advisory Board and bargaining unit worker representatives actively participated in each of the ISMS verifications conducted at Hanford during 2000. This participation allowed Hanford stakeholders and workers to have a better understanding of the processes in place at Hanford for protecting the public, workers and environment.

The Hanford Site's focus has now shifted to maturing and improving the efficiency and effectiveness of ISMS. Some examples include continuing to improve DOE-RL's Environment, Safety, and Health line oversight mechanisms and processes, feedback and improvement mechanisms, and continuing to develop more opportunities for worker participation and feedback at both the task and activity work planning levels.

Rocky Flats Field Office (DOE-RF). The Environment, Safety, and Health Office of Oversight (EH-2) performed a Focused Safety Management Evaluation of the Site from March to April 1999. In its resulting report, EH-2 stated that "....with sustained management attention, the Site is well positioned to achieve full and effective implementation of Integrated Safety Management through the Integrated Work Control Program in a timely manner. The Site made progress on the Corrective Action Plans written and approved from this evaluation to support declaration." In addition, EH-2 concluded that "Rocky Flats Field Office (RFFO) maintains strong operational awareness, performance measure verification, and a readiness overview program to fully meet the expectations of DOE Policy 450.5, Line Environmental, Safety, and Health Oversight."

During 2000, RFFO and the Kaiser-Hill Team continued to develop and implement ISM throughout the Rocky Flats Environmental Technology Site (RFETS). This effort entailed the development and implementation of the Kaiser-Hill Team ISMS, and the incorporation of Department of Energy Acquisition Regulation (DEAR) and DOE P 450.4, Safety Management System Policy, requirements into the management structure, contracts, procedures and practices on the site. Through a series of detailed and 


\section{Annual Report to Congress}

comprehensive reviews conducted by DOE-HQ, RFFO, and the Kaiser-Hill Team, the RFFO Manager concluded that ISM is fully implemented. As a result of these reviews, RFFO also recognized that implementation of ISM is only a beginning, and that an ongoing commitment to the core functions and guiding principles of ISM will be required to meet the Site closure objectives in a safe, compliant and efficient manner.

\section{Defense Programs}

Albuquerque Operations Office (DOE-AL). Phase I ISM verifications were completed at all Albuquerque sites. Phase II ISM verifications were completed satisfactorily at all DOE-AL sites, with one exception. Due to the Cerro Grande fire impacts at Los Alamos, a planned ISM Phase II re-verification was postponed, with its completion now scheduled for April 2001. In addition, a verification of Albuquerque federal ISM responsibilities was recently completed.

DOE-AL is fully committed to implementing ISM consistent with the Secretary's guidance. With the exception of not performing a Phase II re-verification at LANL, Albuquerque met the Secretary's intent of expediting ISM implementation within the DOE community.

Nevada Operations Office (DOE-NV). In early 2000, DOE-NV worked to correct 27 remaining deficiencies (from 87 total) identified in a 1999 review of the Nevada Test Site (NTS) by the Department's Office of Oversight (EH-2). The scope of that review included Defense Programs, DOE-NV, the management and operations contractorBechtel Nevada, Inc., and selected site users and subcontractors. The independent assessment served DOE-NV well as a driving force for improvement in many areas of documentation and implementation. These corrective actions and their status were maintained in the Department's Corrective Action Tracking System (CATS).

DOE-NV worked diligently throughout 2000 to develop and implement a consolidated ISM System that governs all work performed on the NTS. This accomplishment required significant coordination efforts between its contractors, the National Laboratories and their cognizant Operations Offices, and the Defense Threat Reduction Agency.

Work is being conducted safely at the NTS, but the journey from an expert-based to a standards-based safety system is not yet complete. DOE/NV will focus on those opportunities for improvement that were identified in the ISM System Phase II Verification Report, specifically, the contractors' work control and feedback and improvement processes. DOE-NV's goals for 2001 are to complete implementation of 
work control processes, to implement a Phase IIb verification plan, and to have another verification team visit the NTS in May 2001. The Nevada field site is committed to maintaining and improving its ISMS through institutionalization of the continuing core expectations for ISM.

Oakland Operations Office (DOE-OAK). Several Integrated Safety Management verifications were conducted at Lawrence Livermore National Laboratory (LLNL) during calendar year 2000. While ISM verifications at the three LLNL "Superblock" (plutonium, tritium, and hardened engineering) facilities had been completed during September 1999, the balance of the Laboratory's facilities remained to be verified during 2000. Through three separate verification efforts in December 1999, May 2000 and September 2000, the verification teams evaluated ISMS systems from the Director down to activity levels at LLNL. Detailed reviews were conducted on several directorates and specific facilities. The verifications concluded that Integrated Safety Management Systems were defined and implemented at LLNL. DOE-OAK was evaluated during the September 1999, December 1999, May 2000 and August 2000 reviews. The verification teams concluded that OAK had defined and implemented ISMS effectively. 


\section{IMPLEMENTATION OF BOARD RECOMMENDATIONS}

\section{A. Recommendation Closures}

The entire process of opening, acknowledging, addressing, resolving, and closing Board recommendations provides a model for safety oversight processes used in various organizations and at various levels throughout the Department's nuclear complex. The manner in which the Department management acknowledges, addresses, and resolves Board safety issues provides a representative example throughout the Department. Similarly, the manner in which the Board opens safety issues, evaluates resolution approaches, monitors implementation; and ultimately closes safety issues also sets a tone for Department and contractor safety oversight organizations. To be effective, these processes must be understandable and predictable.

When a safety issue is identified by an oversight organization for special attention, there is a tendency to reduce line management control over the resolution of the issue by providing additional management direction and organizational support and advice. For example, additional Department headquarters personnel typically get involved and provide direction to the field for implementation. This can conflict with the guiding safety principle that safety is best served through strong line management ownership that integrates safety into normal work processes. The more quickly that ownership of safety issues is fully integrated into normal line management functions at the working level, the better for safety.

Safety oversight processes that periodically open safety issues and then routinely close them upon substantial resolution serve safety by supporting line management's responsibility for and ownership of safety issues. A routine and orderly process for opening, ressolving, and closing safety issues serves safety by reinforcing the concepts of openness to improvement opportunities, addressing safety issues when identified, and strong line management ownership of safety. Similarly, closure of Board recommendations is beneficial to safety if the following conditions are met: the fundamental safety issues are acknowledged and addressed, the resolution approach is appropriate, the resolution is substantially on target and achieving results, and the organizations and systems are sufficiently mature to integrate continued implementation into ongoing activities. A predictable process for opening, resolving, and closing Board recommendations is also consistent with the original Congressional intent for completion of implementation plans within a relatively short period of time, (i.e., one year). Continued oversight and monitoring is expected on closed Board recommendations to ensure that safety programs and resolutions continue to be 
implemented as needed. If implementation were to degrade, the safety issue would demand renewed management attention.

Department activities culminating in 2000 led to proposed closure of Recommendation 94-1, Improved Schedule for Remediation.

\section{Recommendation 94-1, Improved Schedule for Remediation}

Recommendation 94-1 concerns the need within the Department to address the hazard and risks involving the storage of nuclear materials within the defense nuclear facilities complex. The urgent safety issues described in the recommendation have either been corrected or had compensatory measures put in place to protect workers and the public until stabilization can be completed. Accordingly, with the approval and delivery of the 2000-1 implementation plan in June 2000, the Secretary proposed closure of recommendation 94-1 to the Board. All remaining stabilization activities are being tracked under the implementation plan for recommendation 2000-1.

\section{B. Recommendations Previously Proposed for Closure}

In 1998, the Department completed the last deliverable described in the implementation plan for Board Recommendation 92-4, Multi-Function Waste Tank Facility at the Hanford Tank Farms, and proposed closure of the recommendation.

\section{Recommendation 92-4, Multi-Function Waste Tank Facility at the Hanford Tank $\underline{\text { Farms }}$}

The primary focus of Board recommendation 92-4 was the Tank Waste Remediation System (TWRS) Multi-Function Waste Tank Facility (MWTF) project at the Hanford Site. The recommendation identified three areas of concern: (1) project management structure, (2) design bases (systems engineering) for MWTF, and (3) technical and managerial competence. In developing an implementation plan to address these issues, the Department expanded the scope of its response to apply an integrated systems approach to define, plan, control, and execute the overall Hanford mission. While implementing this approach, the Department re-evaluated the need for the MWTF project, canceled the project, and altered other TWRS projects. The Department completed 38 commitments, including all program management and Site systems engineering commitments, in the first implementation plan and all commitments in a revision to the implementation plan. 
In 1999, the statutory reorganization that established the Office of River Protection (ORP) was fully implemented. With clear lines of authority and accountability within the Department, the Department executed a change to the operating contract for tank farm operations to streamline contract control by the ORP. All River Protection Project (previously TWRS) contracts incorporated requirements for use of the ISMS, and this system's implementation was verified for the operating contractor in 1999. Headquarters staff were organized to support the line management of this program, which encompasses tank farm operations, waste retrieval, processing and disposal. The combined program was designated as a Strategic System by the Department, with key program decisions made by the Secretary.

This implementation plan required more than one year to complete due to the magnitude of applying systems engineering principles to projects at the Hanford Site. The final implementation plan deliverable was completed and provided to the Board in July 1998 and the Department proposed closure of the recommendation in a December 16,1998 , letter to the Board.

\section{New Recommendations and Implementation Plans}

In 2000 the Department accepted two new recommendations received from the Board, Recommendation 2000-1, Stabilization and Storage of Nuclear Material, and 2000-2, Configuration Management, Vital Safety Systems.

\section{Recommendation 2000-2, Configuration Management, Vital Safety Systems}

On April 28, 2000, the Department accepted the Board's recommendation 2000-2 concerning the degrading conditions of vital safety systems and the capability to apply engineering expertise to maintain the configuration of these systems. The Recommendation identified possible degradation in confinement ventilation systems and noted that the Department has not adopted the nuclear business' long-standing practice of designating system engineers for systems and processes that are vital to safety. The Board recommended that the Department take action to assess the condition of its confinement ventilation systems, develop programs for contractor and federal technical personnel that strengthen safety system expertise, and improve the self-assessment processes that evaluate the condition of vital safety systems.

The Department issued an implementation plan under the leadership of the Principal Deputy Assistant Secretary for Environment, Safety and Health. The implementation plan addresses a near-term objective of completing a baseline assessment of the operational readiness of vital safety systems. The Department will identify and 
prioritize actions to correct and/or compensate for degradation to ensure that vital safety systems remain in, or are restored to, their operational readiness condition. As a longterm objective, the Department will institutionalize a process to ensure continued operational readiness of vital safety systems and support the Department's continuing effort to establish Integrated Safety Management (ISM) as the central, enduring framework for safely accomplishing the Department's mission and work. Specific actions described in the implementation plan include:

- Implement a phased approach to assess the current operational readiness of vital safety systems and assess key facilities and/or systems where operability may have degraded. Corrective actions and compensatory actions will be tracked and managed locally to ensure that the operational readiness of these systems is maintained.

- Establish an expert team to develop and test a process for assessing the condition of confinement ventilation systems. Once tested, field element managers will apply the process in facilities at their sites.

- Establish a practice of qualifying contractor technical personnel with system expertise and designating them as system engineers for systems and processes that are important to safety. This practice is expected to enhance the Department's ability to apply engineering expertise in all five functions of ISM.

- Define Federal workforce expertise necessary to support oversight of the contractor's system engineer program. Once defined, the Department will establish qualification requirements for federal personnel relied upon for system expertise. This practice is also expected to enhance the Department's ability to apply engineering expertise in all five functions of ISM.

- Establish a practice that strengthens line management's review of feedback mechanisms by periodically reviewing the scope and results of ES\&H selfassessments and summarizing the results for the Secretary. This practice is expected to provide senior leadership with an executive summary of the results obtained from mechanisms that make up the feedback and improvement function of ISM.

This implementation plan is expected to take more than one year to complete due to the complex and widespread actions necessary. 


\section{Recommendation 2000-1, Stabilization and Storage of Nuclear Material}

The Board issued Recommendation 2000-1 on January 14, 2000. Recommendation 2000-1 reiterates the urgency of completing the nuclear material stabilization activities that were previously committed to under the implementation plan for recommendation 94-1. The recommendation calls for an accelerated schedule for stabilizing and repackaging high risk, unstable special nuclear materials, spent fuel, unstable solid plutonium residues, and highly radioactive liquids that pose potential safety concerns for the public, workers, and the environment. The Department continues to face increased requirements, competing needs, and additional challenges in remediation and storage of materials from disassembled nuclear weapons and materials, materials production processes, and reclamation of former production sites, equipment, and stored products and wastes. Resolving the safety issues encompassed by this recommendation continues to be of the utmost importance.

On March 13, 2000; the Secretary accepted nine of the sub-recommendations dealing specifically with the technical aspects of the Department's material stabilization plans, but did not accept the two sub-recommendations directed at funding requirements. The Secretary approved the implementation plan and provided it to the Board on June 8, 2000. At the time the plan was issued, the Office of Defense Programs outlined a process which they would follow to prepare an integrated plan with milestones for stabilization or discard of remaining legacy materials at Los Alamos National Laboratory. On July 14, 2000, the Board accepted the implementation plan for stabilization activities at the Hanford Site, the Rocky Flats Environmental Technology Site, Lawrence Livermore National Laboratory, and Oak Ridge National Laboratory. The Board expressed concern with regard to plans at the Los Alamos National Laboratory and certain material types at the Savannah River Site.

The Department made significant progress in 2000 toward completing plan deliverables. Significant accomplishments for 2000 include:

- the completion of 12 of the 61 milestones $(20 \%)$ contained in the implementation plan;

- the completion of the movement of all remaining spent fuel at the Idaho National Engineering and Environmental Laboratory to improved storage conditions; 


\section{Annual Report to Congress}

- the initiation of the magnesium hydroxide precipitation process for stabilizing plutonium solution at the Hanford Plutonium Finishing Plant (PFP);

- the initiation of operation of bagless transfer equipment for plutonium packaging at PFP;

- the initiation of fuel movement from the K-West Basin at Hanford to a storage location away from the Columbia River;

- the resumption of operation of bagless transfer equipment for plutonium packaging at the Savannah River Site;

- the revision of the Department's plutonium storage standard, DOE-STD-30132000 , specifying a contamination level for the inner container that is consistent with plutonium stabilization and packaging processes;

- the repackaging of approximately 30,000 kilograms of residues into the pipe overpack component reducing Rocky Flats Environmental Technology Site risk three-fold;

- the continuance of tap-and-draining of remaining process piping in Building 771 at Rocky Flats Environmental Technology Site to remove all remaining solutions; and

- the completion of repackaging of all remaining salt residues, approximately 16,000 kilograms, at Rocky Flats for disposition at the Waste Isolation Pilot Plant.

The Department's 2000-1 implementation plan requires more than one year to complete due to the technical complexity and diversity of materials requiring stabilization at affected defense nuclear sites. A revision to reflect changes in the schedule for stabilization activities at Los Alamos National Laboratory as outlined in the June plan and consistent with the Board's July letter is expected to be issued in early 2001 .

\section{Other Active Implementation Plans}

\section{Recommendation 99-1, Safe Storage of Pits at the Pantex Plant}

The Board issued Recommendation 99-1, Safe Storage of Pits at the Pantex Plant, in August 1999. The recommendation identifies a need for the Department to 
expeditiously resolve issues associated with ensuring the long-term safety of pits, either those held for potential future national security purposes or those identified as surplus to national security needs. The Department accepted Recommendation 99-1 in October 1999 and issued an Implementation Plan on February .1, 2000.

The Department's Responsible Manager for Recommendation 99-1 is the Assistant Deputy Administrator for Military Application and Stockpile Operations (DP-20) in the NNSA Office of Defense Programs.

The Department has taken a number of actions to address the issues associated with long term pit storage and to meet its commitments in the Recommendation 99-1 Implementation Plan:

- Repackaging of pits into the AL-R8 Sealed Insert (SI) container began in July 1999. Of the approximately 13,000 pits planned to be repackaged, 1378 have been completed to date. These containers will provide the appropriate environment to enable safe and reliable storage of pits. Efforts are being made to establish a repackaging rate that will ensure all pits are repackaged within the time frame recommended by the design laboratories to address concerns with the current storage environment. The Department has committed to have two lines and two shifts (four total crews) for pit repackaging, with a goal of 200 pits repackaged per month. Due to competing priorities at Pantex and a lack of Production Technicians, full implementation of this commitment has been delayed until mid-year 2001. Improvements in processes and equipment (shielded workstation, digitally controlled torque station, enhanced imaging station) have been implemented and will continue to be pursued (i:e., automated purge and backfill station and bay organization improvements).

- The Department has evaluated the potential for corrosion of capscrews used in the AL-R8 Sealed Insert pit storage container and has determined a replacement capscrew is warranted. The new corrosion resistant capscrew will be put into service in 2001.

- Pantex has developed the Pantex Pit Management Plan to describe work that is being performed at the site in the area of pit management, actions that need to be taken in the future, constraints of performing this work, and associated risks if the work is not performed. Program schedules and estimated funding requirements are included. 
- Pantex has developed a SI Container Surveillance Program Plan. Surveillance operations for containers are behind schedule but plans are in place to get back on schedule. Some SI containers from one vendor were found to be substandard, but actions are being taken to correct the situation.

- The Department's implementation plan to resolve the issues related to safe storage of pits at Pantex will take longer than 1 year to complete due to the magnitude of the effort. The Department anticipates completion of planned milestones in 2001.

\section{Recommendation 98-2, Safety Management at the Pantex Plant}

The Board issued recommendation 98-2 on September 30, 1998, addressing the need to accelerate safety improvements for nuclear explosive operations at the Pantex Plant. Recommendation 98-2 represents a combination of issues raised in prior Board recommendations and issues identified through more recent staff observations of Pantex activities. The actions undertaken through this implementation plan are aimed at simplifying and standardizing activity level safety management processes for all work involving nuclear explosives at the Pantex Plant.

On September 25, 2000, the Department issued Revision 1 to the implementation plan dated April 23, 1999. Revision 1 introduces a fundamental change in the Department's approach by increasing the focus and priority in making "generic" safety improvements applicable to multiple nuclear weapon processes "across the board." The Department will continue to apply the concepts of SS-21 (Seamless Safety for the 21st Century) to individual weapon processes in accordance with the schedules established; however, the Department believes major safety improvements can be gained by focusing on improved engineered controls applicable to multiple weapon programs and processes. Thus, the Department can achieve tangible improvements in safety on a near-term basis, allowing weapon project teams to focus on further eliminating or reducing hazards through process redesign, as required.

The key accomplishments during 2000 include:

the completion of the first enduring stockpile SS-21 program, W76 D\&I Program. The W76 D\&I SS-21 Program is the first enduring stockpile program to complete the SS-21 process. In addition, approved and implemented weapon-specific hazard analysis for the W88, Step 1, and the W62 Step 1 and re-authorized the W62 operations. 
- the issuance of the DOE approved Pantex Plant Lightning Basis for Interim Operation.(BIO) and updated the Technical Safety Requirements for Pantex Facilities to include the associated lightning controls. The purpose of the lightning BIO analysis and controls is to address the electrical threat from lightning to nuclear explosive operations.

- the issuance of the Flammable Solvent and Combustible Reduction Plan. This plan addresses the elimination and/or reduction of flammable solvent and combustible reduction efforts (Phase 1) through on-going activities and establishes a criterion as part of the SS-21 effort. The plan also addresses the need to establish and develop a systematic process for identifying flammable solvent substitutions (Phase 2).

- the revision of the AL 56XB, Development and Production (D\&P) Manual, Chapter 11.7, to define and streamline Nuclear Explosive Operations Change - Control Process expectations in order that the Pantex Plant Management and Operating (M\&O) Contractor may systematically implement these practices for all nuclear explosives operations at Pantex.

- the development and release of D\&P Manual, Chapter 11.8, to define the methodology for developing and applying weapon response information to the process of identifying and classifying controls for nuclear explosive operations at the Pantex Plant for Pantex Plant M\&O contractor and national laboratories implementation.

- the release of the BIO/SAR Program Plan. This plan documents Pantex Plant's intent and pathway to establish and integrate safety basis documentation into a single, site Safety Analysis Report.

- the implementation of significant improvements in the Pantex fire protection strategy. Through detailed analysis of facility and process combustibles, Pantex implemented a detailed strategy to eliminate, reduce, or contain combustibles for the W76 program. The Fire Basis for Interim Operation module, under final DOE review for approval, implements enhanced combustible cortrols for all nuclear explosives operations and upgrades the fire suppression system to fast acting ultraviolet detector actuated deluge system.

The Department's implementation plan represents an aggressive ștrategy for improving safety management processes for nuclear explosive operations at the activity level. This implementation plan has taken more.than one year to complete due to the magnitude and complexity of the changes. Some of these changes are cultural in 


\section{Annual Report to Congress}

nature; they related to long-term, deep-rooted assumptions and ways to do business. This plan is currently scheduled for completion in 2003.

\section{Recommendation 98-1, Resolution of Safety Issues Identified by Internal Independent Oversight}

On September 28, 1998, the Board issued Recommendation 98-1 to address and resolve safety issues identified by internal independent oversight. The Secretary accepted the recommendation on November 20,1998, and established the Department's implementation plan on March 10, 1999. The implementation plan identified specific actions to improve the Department's corrective action process, addressing the following elements: roles and responsibilities, issue/dispute resolution process, senior management involvement, contents of corrective action plans, tracking and reporting, and verification of corrective action effectiveness. The implementation plan has been managed as part of the Department's integrated safety management program.

The key accomplishments in accordance with the Department's implementation plan during 2000 include:

- In January 2000, the Department established its review plan for verifying effective implementation of the process for resolving issues identified by the Office of Independent Environment, Safety and Health Oversight.

- In January, April, July, and October 2000, the Department issued its Quarterly Report on corrective action status and presented this information to the Department's senior managers.

- In January and May 2000, the Department provided periodic reports to the Board on implementation plan progress at the Board's public meetings on integrated safety management. In March 2000, the Department provided written answers to the Board's reporting requirements of February 2000, following the January 2000 public meeting. In September 2000, the Department provided written answers to the Board's reporting requirements of July 2000 , following the May 2000 public meeting.

- In March 2000, the Department completed an assessment of the effectiveness of the DOE's Corrective Action Tracking System (CATS). The report reflects an assessment of the ownership, funding, maintenance, and effectiveness of the CATS, as well as a discussion of system improvements. The Department concluded that the CATS database is effectively performing the status tracking functions for which it was designed. 
- In April 2000, the Office of Independent ES\&H Oversight published its Safety Issue Corrective Action Process Procedure, which outlines the internal framework for monitoring the Department of Energy process for addressing and resolving Safety Issues identified during the conduct of Oversight appraisal activities. The procedure delineates the Office of Oversight process for entering Safety Issues identified during the conduct of appraisal activities in the DOE Corrective Action Tracking System, evaluation of line management corrective action plans (CAPs), and resolution of disagreements concerning the CAPs.

- In June 2000, the Department issued its May 31, 2000 verification report on progress toward implementing the corrective action management process described in the Department's March 10,1999 plan. The report concludes that substantial progress has been made. However, the verification team identified two areas for additional attention: (1) institutionalization of process requirements in the roles, responsibilities, authorities, and procedures at the Program Secretarial Office and Field Office levels; and, (2) forging of a stronger link between the corrective action management process and the Department's lessons learned program.

- In July 2000, the Department established its corrective action plan in response to the verification findings.

- In October 2000, the Department approved the charter of the Corrective Action Management (CAM) Team, which will coordinate ongoing implementation of the corrective action management process. Leadership of the CAM Team is shared by two co-chairs, one from a line program office and one from the Office of Independent Environment, Safety and Health Oversight. The executive sponsor of the program is the Deputy Assistant Secretary, Office of Independent Environment, Safety and Health Oversight.

- In November 2000, the CAM Team developed a proposed process for evaluating potential additions to the scope of the corrective action tracking system. The proposed process is designed to prevent dilution of the system's original purpose and effectiveness at providing visibility for a specific set of safety items of interest to the Office of the Secretary.

As originally conceived in March 1999, this plan was scheduled for completion by June 2000. More than one year has been required for completion of this plan due to the need to assure that process changes have been adequately implemented and institutionalized as part of the ongoing safety management structure. At this point, all actions described 
in the plan are complete. The only ongoing activity is completion of institutionalization of the developed process by incorporation of appropriate process requirements in Functions, Responsibilities, and Authorities documents and the Quality Assurance Plans for major field and program offices. As of January 2001, over $80 \%$ of the offices have completed institutionalization of these process requirements. The Department anticipates completion of this institutionalization process and proposal of closure for this recommendation by April 2001.

\section{Recommendation 97-2, Criticality Safety}

The Board issued Recommendation 97-2 on May 19, 1997, addressing the effectiveness of criticality safety programs at defense nuclear facilities in the Department complex. This recommendation identified the need for the Department continue to assure criticality safety effectively and efficiently in current and future operations. This recommendation continued and expanded previous Board recommendation 93-2, Critical Experiment Capability.

The Department developed an implementation plan which outlines a comprehensive strategy to improve the efficiency of criticality safety programs within the Department. The key accomplishments related to recommendation 97-2 during 2000 were:

- The Department continued to preserve important criticality safety related information and make it available through its web sites. The International Criticality Safety Benchmark Evaluation Program published 22 new evaluations. This brings the total of published benchmark evaluations to 284 which includes 2352 critical configurations that can be used by criticality safety engineers for validating criticality safety evaluation calculations.

- Technical knowledge of criticality safety personnel was enhanced through the training course at Los Alamos, development of additional training materials, which can be accessed through the worldwide web, and implementation of qualification standards for federal and contractor criticality safety personnel. The majority of federal staff with criticality safety oversight responsibilities are qualified under the new standard, and contractors will be required to qualify their criticality safety staff as well.

- The Criticality Safety Support Group was used extensively during 2000 to provide expert support in a number of areas. Members of the group participated in criticality safety program reviews at the Hanford Plutonium Finishing Plant, Rocky Flats Building 371, and the East Tennessee Technology Park at Oak Ridge. At the request of the Offices of Defense Programs. and Environmental 
Management, the Criticality Safety Support Group reviewed contractor criticality safety self-assessments. The Criticality Safety Support Group also provided technical advice to the Office of Environment, Safety, and Health in the revision and update of Departmental directives. All of these activities supported the Secretarial initiative aimed at strengthening Departmental criticality safety programs.

The Department's implementation plan represents an aggressive strategy for improving criticality safety programs to ensure efficient support of ongoing fissile material activities. However, the Department will require more than one year to implement this plan due to the magnitude and scope of the actions. To date, 28 of 30 commitments are complete. The last action, the establishment of dates by which contractors will have implemented qualification programs, is scheduled for completion in May 2001.

\section{Recommendation 97-1, Safe Storage of Uranium-233 $\left({ }^{23} \mathrm{U}\right)$}

The Department has an inventory of approximately two metric tons of ${ }^{233} U$ in many different forms stored under a variety of conditions throughout the complex. The majority is located at the Oak Ridge National Laboratory and the Idaho National Engineering and Environmental Laboratory, with much smaller quantities at Los Alamos National Laboratory and even smaller quantities at numerous other sites. The material exists in various forms, as oxides, metal, solutions, and fluorides.

Recommendation 97-1 expressed the Board's concern regarding the safe storage of ${ }^{233} \mathrm{U}$ at various sites in the Department's complex. The primary safety issue described within the recommendation is the lack of material characterization and uncertainty of storage conditions for ${ }^{233} \mathrm{U}$. The recommendation had been preceded in February 1997 by a Board technical report entitled Uranium-233 Storage Safety at Department of Energy Facilities. The report describes the Board's perspective of the safety of ${ }^{233} \mathrm{U}$ stored at various sites in the Department's complex. This formed the basis for the Board's recommendations. The Department responded with an implementation plan that was based on a systems engineering approach. A unique feature of this implementation plan was the recognition that all necessary actions could not be defined up front thereby providing for a Program Execution Plan to succeed the implementation plan once the total set of actions were known. The Program Execution Plan, which was provided to the Board in 1999, was the final deliverable under the implementation plan.

The Department continues to use a systems engineering approach to manage the actions under the Program Execution Plan, and to consider long term options for the ${ }^{233} \mathrm{U}$ inventory such as long term storage, disposition as excess material or possible beneficial use. Key activities completed in 2000 include: 
- The Department issued the final standard, DOE-STD-3028, in July 2000 for packaging and storing ${ }^{233} \mathrm{U}$ bearing materials. The new standard has been used at Oak Ridge to establish the processing parameters for conversion of uranyl nitrate to uranium oxide following the extraction of medical isotopes, for defining calcination temperatures and moisture measurements, and as the technical basis for the planning of the inspection of a sampling of containers stored in the Building 3019 tube vaults.

- Preparations for the initiation of the inspection of containers at Oak Ridge achieved two key milestones. The Building 3019 Safety Analysis Report and Technical Safety Requirements were submitted to the Department for approval on September 28, 2000. The testing of the inspection equipment in the cold mock-up facility was completed in October. Final testing of the equipment using test containers in empty storage tubes in the Building 3019 Penthouse was initiated in December. Integrated testing of equipment, procedures, and support functions are planned for early 2001.

- At the Idaho National Engineering and Environmental Laboratory, the vaults holding the unirradiated Light Water Breeder Reactor fuel were inspected and the head space gases analyzed. There was no indication of any degradation of the conditions under which the material is being stored or that the material is undergoing degradation. Planning for the future use and disposition of this inventory was initiated in August and is expected to be complete in 2002.

- The Department completed a set of draft engineering studies to screen possible disposition options for the ${ }^{233} \mathrm{U}$ addressed within the scope of the recommendation. The studies examined processes that would reduce the ${ }^{233} \mathrm{U}$ enrichment to a "non-weapons usable" status and produce a packaged waste form that was suitable for repository disposal.

In mid-year the Secretary announced steps to expand the Department's capacity to provide an isotope extracted from leftover radioactive materials used in nuclear activities to support clinical trials for the treatment of several forms of cancer. Plans call for increasing the near term supply of the isotope Bismuth-213 $\left({ }^{13} \mathrm{Bi}\right)$, a decay product of ${ }^{233} \mathrm{U}$ currently in storage at the Department's Oak Ridge National Laboratory, and make it available to medical researchers. To ensure that an ample supply of this isotope is available for the long term once trials are proven successful, the Department began preparing a Request for Proposal (RFP) in the fall of 2000. The RFP solicits proposals by private contractors for extraction of the medical isotopes and preparation of the ${ }^{233} \mathrm{U}$ material for safe long term storage. 
This plan has taken more than one year to complete. At present, all milestones are complete.

\section{Recommendation 96-1, In-Tank Precipitation System at the. Savannah River Site}

The Board issued recommendation 96-1 on August 14, 1996, to address concerns at the In-Tank Precipitation (ITP) facility related to potential generation and release of flammable benzene in the primary process tank. This recommendation identified the need for improved understanding of the mechanisms leading to the generation, retention, and release of benzene, and based on this understanding, evaluation of the adequacy of existing safety measures and development of additional safety measures as necessary.

ITP is the process step in the vitrification of unstable hazardous radioactive and chemical liquid wastes that precipitates the highly radioactive salt fraction of liquid high-level waste to allow for vitrification of the wastes by the Defense Waste Processing Facility. ITP began operations in September 1995, treating the first batch of high-level waste with sodium tetraphenylborate (TPB) to precipitate cesium and sodium titanate (MST) to adsorb uranium, plutonium and strontium. Following several startup tests, slurry pumps were being operated on December 1, 1995, prior to sampling the tank, when benzene in quantities greater than expected was first observed. Since December 1995, the Department has been performing analysis and testing to better understand the observed benzene phenomenon.

Chemistry test program results have determined that TPB breaks down into intermediate products, producing benzene as each product decomposes. Certain waste components accelerate the decomposition reaction. Test results have indicated that benzene generation rates produced from decomposition reactions will cause benzene release rates to exceed the capacity of current plant hardware/systems. Not only does sodium TPB decompose, but potassium and cesium TPB can also decompose rapidly under certain conditions, threatening the ability to maintain the salt solution until prepared for vitrification processing at DWPF.

In January 1998, it was concluded that high benzene generation rates and precipitate solids instability would not support the ITP process as currently designed. As a result, ITP restart preparations were suspended pending the outcome of a system engineering evaluation of potential options for removing cesium from stored high level waste solutions. The Westinghouse Savannah River Company completed the alternatives evaluation in November 1998; however, DOE-SR concluded that additional R\&D was required to address uncertainties associated with the final "short list" alternatives before a preferred alternative could be selected. The additional R\&D was completed in 
October 1999, but there were still significant technical uncertainties associated with the cesium-removal technologies. In December 1999, DOE-SR recommended to the Assistant Secretary for Environmental Management (EM-1) that additional R\&D be performed to resolve the key technical uncertainties with the cesium-removal technologies until a preferred alternative with a high probability for success can be selected. In March 2000, an Action Plan was approved and issued by EM-1 describing the management approach for performing additional R\&D and for developing and applying criteria to support selection of a preferred alternative(s). The additional R\&D was to be conducted over a 12 month period to allow evaluation of R\&D results and selection of a preferred alternative(s) by June 2001. At the close of 2000, identified $R \& D$ activities are proceeding on schedule to support a June 2001 down-selection.

In addition to R\&D activities for salt disposition alternatives, activities began in 2000 to disposition material in Tank 49 so that the tank can be returned to normal high-level waste storage service. The phenylborate compounds remaining in Tank 49 from the 1983 In-Tank Precipitation Demonstration continue to decompose over time, releasing benzene and rendering Tank 49 unsuitable for Tank Farm service until the waste is dispositioned. Although Tank 49 slurry pump operations commenced in February 2000 to deplete any benzene retained in solution, phenylborate decomposition continues at a very slow rate, extending the time before Tank 49 can be returned to Tank Farm service. To expedite the return to Tank Farm service, a disposition plan and associated safety basis has been established for dispositioning the remaining phenylborate compounds in Tank 49 by heating and treating (catalyzing with copper nitrate) the material. This plan and safety basis has been developed with the benefit of interaction with the Board Staff and has been briefed to the Board. The heat-up of Tank 49 material has commenced, with copper nitrate catalysis initiated in early 2001.

Other than the disposition of Tank 49 material and subsequent return of Tank 49 to Tank Farm service, no further action with regard to resolution of 96-1 issues is planned until a preferred alternative is selected.

\section{Recommendation 95-2, Integrated Safety Management}

Recommendation 95-2 called for: (1) an institutionalization process for ensuring environment, safety and health requirements are met; (2) graded safety management plans for the conduct of operations; (3) a prioritized list of facilities based on hazards and importance; (4) direction and guidance for the safety management process; and (5) measures to ensure availability of technical expertise to implement the streamlined process effectively. The Department's April 1996 implementation plan describes the Department's approach for implementing these recommendations. 
Key accomplishments for 2000 are summarized below:

- The Department made significant progress in implementing ISM in 2000. Thirty-one Phase II ISM verifications were conducted during the year and ISM was reported initially implemented by all but two field offices in time to meet the Secretary's September 30, 2000 target date. The two remaining field offices have established April 2001 as the date for their completion of initial implementation at their facilities. In addition, except for the program office responsible for the above two field offices, all other program offices have reported to the Deputy Secretary that ISM had been successfully implemented at their sites and facilities.

- In his September 28, 2000, memorandum, Realizing the Benefits of Integrated Safety Management, to the heads of all Departmental elements, the Deputy Secretary established a number of follow-on tasks for sustaining ISM systems and improving performance.

- In response to the Deputy Secretary's December 3, 1999, direction, a Quarterly Performance Measures Report was developed by the Safety Management Implementation Team to report on five complex-wide performance indicators that could be useful to the Deputy Secretary and Field Management Council members for tracking safety-related performance at field sites. Three such quarterly reports were generated in 2000 and a process for maturing the performance measures set was initiated.

- The Department participated in two meetings - January 20, 2000; and May 31, 2000 - chaired by the Board on the subject of Integrated Safety Management. Both meetings were open to the public and involved testimony for the public record by senior DOE and contractor officials.

- An ISM Institutionalization Workshop was held at DOE Headquarters on March 29,2000 , to examine the functions and elements necessary to ensure a continuing focus on ISM in the months and years ahead.

- A Review Team Report on the Effective Implementation of the Process for Resolving Issues Identified by the Office of Oversight was published on May 31,2000 . This report provided an assessment on how well the Department had implemented its corrective action management program (in response to 
Recommendation 98-1) as part of the feedback and improvement process of the Integrated Safety Management program.

- Eleven videoconferences were conducted between DOE senior managers and the DNFSB in September and October 2000 for the purpose of reviewing the status of implementation of ISM throughout the complex.

- The Program and Field Offices developed Functions, Responsibilities and Authorities (FRA) documents that are in consonance with the corporate Functions, Responsibilities and Authorities Manual (FRAM), DOE M 411.1.

- The Richland Operations Office, the Office of River Protection and major Hanford contractors sponsored a successful ISM Lessons Learned Workshop in Pasco, Washington, December $5-6,2000$, that was attended by several field managers, a Board member, Board staff, and approximately 700 other Department and contractor personnel. The Workshop focused on the continuing requirements to ensure an effective ISM program is maintained.

- An upgraded ISM Resource Center Web site was established in December 2000 to facilitate the compilation and dissemination of information related to the Department's safety management initiatives.

In summation, the Department's leadership is solidly behind ISM. Three successive Secretaries of Energy have endorsed ISM as the enduring framework for managing the safe performance of work throughout the DOE complex. While it is widely recognized that the Department has largely achieved initial implementation, there is also no doubt as to the continuous challenge that lies ahead. ISM is a journey, not a destination. The Department is committed to operating within the excellent framework that ISM provides and to doing work safely.

This plan has taken more than one year to complete due to the significant cultural and process changes being addressed. At this time, all plan deliverables are complete.

\section{E. Report on Implementation Plans Requiring More Than One Year}

When the Congress established the Board, they envisioned that the Department would typically be able to resolve Board recommendations within a relatively short period of time, such as within one year after the Department submits its implementation plan. To monitor the Department's performance in completing implementation plans, Congress included a provision in the Board's enabling legislation that requires notification from the Department to Congress whenever the Department takes more than one year to 
complete an implementation plan in response to a Board recommendation. The enabling legislation also requires the reasons for requiring more than one year and the expected completion date.

The Department has required more than one year to complete a number of implementation plans for Board recommendations. This has occurred for a variety of reasons including the size and scope of issues being addressed and challenges in accomplishing complex-wide changes. The Department routinely makes the required Congressional notification in conjunction with the Department's Annual Report to Congress on Board activities (i.e., this report), which is also required by the Board's enabling legislation. In accordance with Chapter 21, Section 315 of the Atomic Energy Act of 1954 [42 U.S.C. $\S 2286 \mathrm{~d}(\mathrm{f})(1)$ ], the following active implementation plans are expected to require a total of more than one year to complete:

- $\quad$ 95-2, Safety Management ${ }^{1}$

- 96-1, In-Tank Precipitation System ${ }^{1}$

- $\quad 97-1$, Safe Storage of Uranium-233 ${ }^{1}$

- $\quad 97-2$, Criticality Safety $^{1}$

- $\quad$ 98-1, Resolution of Internal Oversight Findings ${ }^{1}$

- $\quad$ 98-2, Safety Management at the Pantex Plant ${ }^{1}$

- $\quad$ 99-1, Safe Storage of Pits at the Pantex Plant ${ }^{1}$

- $\quad 2000-1$, Stabilization and Storage of Nuclear Material

- 2000-2, Configuration Management, Vital Safety Systems

The associated reasons and expected completion schedules for each implementation plan were provided with the previous discussion of Department activities for each Board recommendation.

\section{F. Categorization of Board Recommendations}

There are a number of ways to group and categorize Board recommendations. These groupings provide insights into the types of safety issues the Department is addressing and the schedules for issue resolution.

'Previously reported to require more than one year to implement.

'Previously reported to require more than one year to implement. 


\section{Scope of Organizations Involved}

Recommendations vary in the scope of organizations involved and are categorized as: (1) Department-wide, (2) multiple-sites/multiple-organizations, and (3) singlesite/single-organization. In general, the more organizations that are involved, the more complex and time-consuming the resolution. Department-wide recommendations are most likely to involve complex management and coordination efforts, and are also more likely to involve management culture changes, which require more time and attention to assimilate. Single-site recommendations are often of a more technical nature, while complex-wide recommendations often involve management issues. Tables 3.A - 3.C show the scope of organizations involved for open Board recommendations and also those closed over the past three years.

Table 3.A - Department-Wide Recommendation

\begin{tabular}{||c|c||}
\hline Open Recommendations & Closed Recommendations (1998-2000) \\
\hline $\begin{array}{c}\text { 2000-2, Configuration Management, Vital Safety } \\
\text { Systems }\end{array}$ & $94-5$, Rules, Orders, and Other Requirements \\
\hline $\begin{array}{c}\text { 2000-1, Stabilization and Storage of Nuclear } \\
\text { Material }\end{array}$ & $94-2$, Safety Standards for Low Level Waste \\
\hline $\begin{array}{c}\text { 98-1, Resolution of DOE Internal Oversight } \\
\text { Findings }\end{array}$ & $93-3$, Improved Technical Capability \\
\hline $\begin{array}{l}\text { 95-2, Safety Management } \\
\text { 94-1, Improved Schedule for Remediation }\end{array}$ & \\
\hline
\end{tabular}

Table 3.B - Multiple-Site/Multiple-Organization Recommendations

\begin{tabular}{||l|l||}
\hline \multicolumn{1}{|c|}{ Open Recommendations } & \multicolumn{1}{|c|}{ Closed Recommendations (1998-2000) } \\
\hline $97-2$, Criticality Safety & $93-6$, Nuclear Weapons Expertise \\
\hline $97-1$, Safe Storage of Uranium-233 & $\begin{array}{l}\text { 93-1, Standards Utilization at Defense Nuclear } \\
\text { Programs }\end{array}$ \\
\hline
\end{tabular}


Table 3.C - Single-Site/Single-Organization Recommendations

\begin{tabular}{||c|c||}
\hline Open Recommendations & Closed Recommendations (1998-2000) \\
\hline 99-1, Safe Storage of Pits at the Pantex Plant & $\begin{array}{c}\text { 95-1, Improved Safety of Cylinders Containing } \\
\text { Depleted Uranium (Oak Ridge) }\end{array}$ \\
\hline $\begin{array}{c}\text { 98-2, Safety Management at the Pantex Plant } \\
\text { 96-1, In-Tank Precipitation Facility (Savannah } \\
\text { River) }\end{array}$ & $\begin{array}{c}\text { 94-4, Deficiencies in Criticality Safety at Oak } \\
\text { Ridge Y-12 }\end{array}$ \\
\hline & $94-3$, Rocky Flats Seismic and Systems Safety \\
\hline 93-5, Hanford Waste Tanks Characterization \\
\hline $\begin{array}{c}92-4, \text { Multi-Function Waste Tank Facility at } \\
\text { Hanford (proposed)* }\end{array}$ \\
\hline
\end{tabular}

* Closure Proposed on 12/16/98

**Closure Proposed on 6/8/2000

\section{Lead Implementing Organization}

Most Department implementation plans are managed from Department headquarters organizations Table 3.D, 3.E, and 3.F show the lead organization for different open recommendations.

\section{Table 3.D - Lead Organization: Environmental Management}

\begin{tabular}{||l||}
\hline Open Recommendations \\
\hline 2000-1, Stabilization and Storage of Nuclear Material \\
\hline $97-1$, Safe Storage of Uranium-233 \\
\hline 96-1, In-Tank Precipitation Facility (Savannah River Operations Office) \\
\hline $94-1$, Improved Schedule for Remediation \\
\hline
\end{tabular}

Table 3.E - Lead Organization: Defense Programs

\begin{tabular}{||l||}
\hline Open Recommendations \\
\hline 99-1, Safe Storage of Pits at the Pantex Plant \\
\hline 98-2, Safety Management at the Pantex Plant \\
\hline 97-2, Criticality Safety \\
\hline
\end{tabular}


Table 3.F - Lead Organization: Other Headquarters Organizations

\begin{tabular}{|c|}
\hline Open Recommendations \\
\hline $\begin{array}{l}\text { 2000-2, Configuration Management, vital Safety Systems (Office of Environment, Safety } \\
\text { and Health) }\end{array}$ \\
\hline 98-1, Resolution of Internal Oversight Findings (Office of the Deputy Secretary) \\
\hline 95-2, Safety Management (Office of the Deputy Secretary) \\
\hline
\end{tabular}

\section{Progress Toward Completion of Implementation Plans}

Implementation plans with long-term completion dates involve more uncertainty than those with shorter completion schedules. The projected deliverables and schedules are less certain the further out are the projected plan due dates. The long-term plans often involve research, development and application of new techniques. Due to the nature of these activities, the schedules are less certain and the basic direction of the plan may need to be substantially changed based on the outcome of intermediate activities. For plans to be effective and useful, it must be understood that plan deliverables and milestones can not be known with certainty several years in advance and should not be held rigid in light of new information and new priorities. Flexibility is required in adjusting plan deliverables and milestones as the plan is being executed, particularly for plans that extend more than the one year that the Congress envisioned for typical implementation plan completion. Table 3.G, 3.H, and 3.I show the status of implementation plans based on anticipated completion dates.

\section{Table 3.G - Implementation Plans Complete}

\begin{tabular}{||l||}
\hline Open Recommendations \\
\hline $98-1$, Resolution of Oversight Findings \\
\hline 97-1, Safe Storage of Uranium-233 \\
\hline 95-2, Safety Management \\
\hline 94-1, Improved Schedule for Remediation \\
\hline 92-4, Multi-Function Waste Tank Facility at Hanford \\
\hline
\end{tabular}


Table 3.H - Implementation Plans Projected to be Complete in 2001

\begin{tabular}{|l||}
\hline Open Recommendations (Projected Completion) \\
\hline 99-1, Safe Storage of Pits at the Pantex Plant (2001) \\
\hline 97-2, Criticality Safety (2001) \\
\hline 96-1, In-Tank Precipitation Facility at Savannah River (Pending outcome of alternatives review) \\
\hline
\end{tabular}

Table 3.I - Implementation Plans Projected to be Complete After 2001

\begin{tabular}{||l||}
\hline Open Recommendations (Projected Completion) \\
\hline 2000-2, Configuration Management, Vital Safety Systems (2002) \\
\hline 2000-1, Stabilization and Storage of Nuclear Material (2010) \\
\hline 98-2, Safety Management at the Pantex Plant (2001) \\
\hline
\end{tabular}




\section{OTHER BOARD INTERFACE ACTIVITIES}

The Department shares with the Board the common goal of ensuring adequate protection at its defense nuclear facilities of the health and safety of the public. To accomplish this goal, the Department's policy has been to:

- fully cooperate with the Board;

- provide access to information necessary for the Board to accomplish its responsibilities;

- thoroughly consider the recommendations and other safety information provided by the Board;

- consistently meet commitments to the Board; and

- conduct interactions with the Board in accordance with the highest professional standards.

The Office of the Departmental Representative to the Defense Nuclear Facilities Safety Board (Departmental Representative) manages the Department's overall interface with the Board and provides advice and direction for resolving identified safety issues.

The Board and its staff have made a positive impact on Department safety across a wide variety of issues during 2000 , particularly the development and accelerated implementation of ISM, and continued improvement in safety directives. The dialog between the individual Board members and senior Department officials has been frank and open regarding improvements. As a result of interaction with the Board and its staff, the Department now has a more complete and effective set of safety requirements and expectations, and a more thorough understanding of how each of the previous safety requirements were addressed during the transition. The Board has also been instrumental in the development of Department guidance for incorporating new safety requirements into contracts and accomplishing contractor implementation.

\section{Coordination of Board Review of Department Safety Directives}

One of the Board's significant responsibilities is the review and evaluation of the Department's safety directives and standards that apply to the design, construction, operation, and decommissioning of Departmental defense nuclear facilities. In keeping with this function, the Board has reviewed the body of the Department's directives (including rules, policies, notices, orders, manuals, handbooks, guides, and standards) 
and identified those specific directives "of interest" to the Board. Whenever the Department develops changes to these identified directives or identifies new directives potentially "of interest" to the Board, the Board is provided an opportunity to review and comment on the changes prior to approval by Department management. The Office of the Departmental Representative coordinates this review process with the Board to ensure that the Board and it's staff are notified of each change and given an opportunity for review and comment prior to issuance. Appendix $A$ (refer to page A-1) provides a listing of the orders identified as "of interest" to the Board, and a listing of Departmental safety directives "of interest" to the Board that were changed in 2000.

\section{Briefings, Site Visits, and other Board Interactions}

The Department has continued to interact extensively and effectively with the Board and it's staff. Department personnel supported over 180 site briefings and site visits by the Board or it's staff in 2000. This has included provision of logistical and technical support and interface, as appropriate, to facilitate unrestricted access by the Board and its staff to the Department's facilities. Appendix $B$ (see page B-1) provides a summary of site visits supported by the Department during 2000. In addition, Department personnel conducted numerous teleconferences and video conferences to exchange information and resolve safety issues.

In 2000, the Department and the Board exchanged over 185 items of correspondence (not including transmittal of requested information and routine distribution of assessments and evaluations). A large portion of the written communications involves the Board's recommendations and the associated deliverables, schedules, and reporting requirements contained in the Department's implementation plans. In addition, the Department receives and responds to trip reports detailing visits by the Board or its staff to Department facilities. It also receives specific requests from the Board or its staff for particular information or action by the Department. Appendix $C$ (on page C-1) provides a summary of key correspondence between the Department and the Board for 2000 .

\section{$\underline{\text { Responses to Board Reporting Requirements }}$}

The Board communicates with the Department through a variety of channels including formal recommendations and reporting requirements, through letters requesting action and information, and through letters providing suggestions and information such as staff issue reports and trip reports. Communication channels also include Board and Board staff requests for information, public meetings, briefings and discussions, and site visits. The Board's choice of communication means suggests the level of the Board's concern, with the more formal channels used for clearly-defined safety issues that require prompt attention by Departmental managers. During 2000, the Board issued seven sets of 
formal reporting requirements, pursuant to Chapter 21, Section 313 of the Atomic Energy Act of 1954 [42 U.S.C. 2286b(d)], as shown in Table 4.A.

\section{Table 4.A - Defense Nuclear Facilities Safety Board Year 2000 Formal Reporting Requirements}

\begin{tabular}{|c|l|c|}
\hline Date & \multicolumn{1}{|c|}{ Topic of Reporting Requirements } & $\begin{array}{c}\text { Days for } \\
\text { Report }\end{array}$ \\
\hline $1 / 20 / 00$ & $\begin{array}{l}\text { Technical Report 25 regarding Quality Assurance for Safety- } \\
\text { Related Software }\end{array}$ & 60 \\
\hline $2 / 16 / 00$ & $\begin{array}{l}\text { Provide response to Board's questions on information submitted } \\
\text { for public record at the public meeting on January 20th }\end{array}$ & 30 \\
\hline $5 / 2 / 00$ & $\begin{array}{l}\text { Evaluate Pantex systemic deficiencies in fire hazard analyses and } \\
\text { controls }\end{array}$ & 60 \\
\hline $7 / 20 / 00$ & $\begin{array}{l}\text { Provide response to Board's questions from the public meeting on } \\
\text { May 31st }\end{array}$ & 45 \\
\hline $8 / 29 / 00$ & $\begin{array}{l}\text { Address issues identified on High-Level Waste Tank Integrity } \\
\text { Program at Hanford }\end{array}$ & 90 \\
\hline $10 / 23 / 00$ & Implementation of the Lightning Basis for Interim Operation & 30 \\
\hline
\end{tabular}

The Board's reporting requirements and the Department's responses are available on the Departmental Representative's web site at http://www.deprep.org.

\section{Board Public Meetings}

The Board holds public meetings periodically to review significant safety and management issues in a public forum. The Board provides advance public notice for these meetings pursuant to the provision of the "Government in the Sunshine Act" (5 U.S.C. § 552b). During 2000 , the Department supported the following fiver public meetings conducted by the Board as listed in Table 4.B. 
Table 4.B - Defense Nuclear Facilities Safety Board Year 2000 Public Meetings

\begin{tabular}{|c|l|c|}
\hline Date & \multicolumn{1}{|c|}{ Topic of Public Meeting } & Location \\
\hline $2 / 9 / 00$ & $\begin{array}{l}\text { Oversight of the Department of Energy's defense nuclear } \\
\text { facility safety management program }\end{array}$ & $\begin{array}{c}\text { Amarillo, } \\
\text { TX }\end{array}$ \\
\hline $4 / 5 / 00$ & $\begin{array}{l}\text { Oversight of the Department of Energy's defense nuclear } \\
\text { facility safety management program }\end{array}$ & $\begin{array}{c}\text { Oak Ridge, } \\
\text { TN }\end{array}$ \\
\hline $5 / 31 / 00$ & $\begin{array}{l}\text { Status of activities associated with the Department's } \\
\text { implementation plans for integrated safety management } \\
\text { (Recommendation 95-2) and resolution of oversight findings } \\
\text { (Recommendation 98-1) }\end{array}$ & $\begin{array}{c}\text { Washington, } \\
\text { DC }\end{array}$ \\
\hline $11 / 30 / 00$ & $\begin{array}{l}\text { Utilization of F- and H- Canyon Facilities at Savannah River } \\
\text { Site }\end{array}$ & Aiken, SC \\
\hline
\end{tabular}

\section{Secretary of Energy Quarterly Briefings with the Board Members}

The Secretary initiated scheduled quarterly briefings between the Board members and senior Department management in 1994. Periodic briefings continued during 2000. The Department typically is represented in these quarterly sessions by the Secretary, Deputy Secretary, Under Secretary, and the Departmental Representative. This forum facilitates senior level information exchange on key safety and management issues, and on relative priorities and directions.

\section{Safety Issues Management System}

The Department established a Department-wide commitment management tool, the Safety Issues Management System, in August 1995. Using this tool, the Department has reduced the number of outstanding commitments related to Board recommendations from 694 in August 1995 to 109 in December 2000. The total number of overdue commitments related to Board recommendations has also declined significantly, from 245 in August 1995 to 21 in December 2000. In addition to commitments and actions related to Board recommendations, the Safety Issues Management System is also used to manage commitments and actions related to other interactions between the Department and the Board, such as Board requests for action or information and Department commitments in letters to the Board. Since these "letter . commitments" were first tracked in mid 1996, 316 letter commitments have been identified of which 299 have been completed.

The Office of the Departmental Representative conducts qualitative and technical reviews of the Department's implementation plans and other outgoing correspondence to the Board to 
identify and capture Department commitments. Commitment information identified from these documents is entered into the Safety Issues Management System database. Monthly summary reports on the status of commitment implementation or completion are distributed to responsible Department managers, points of contact, and Secretarial Officers. These personnel can access detailed information and use various view, sort, and report formats via an on-line, Internet-based user interface.

\section{Information Archive of Board-Related Documents}

The Departmental Representative maintains an information archive of all Department/Board correspondence, reports, plans, assessments, and transmittals. In 1996, the Departmental Representative began transferring the archived information onto a dedicated Internet web site, thus increasing accessibility within the Department complex and by the general public. During 1997 and 1998, the web site was substantially expanded and made more user-friendly. The objectives of the web site upgrade effort were to improve communications and coordination among Department interface personnel, to save time and money by eliminating paper distribution where practical, and to provide an effective web-based tool for interface personnel to research safety and management issues. At present, approximately 1,700 individual documents are provided on the web site. New documents are added promptly upon receipt.

The following types of documents are included in the information archive:

- Board recommendations;

- Department responses and implementation plans;

- Department letters to the Board;

- Board letters to the Department;

- selected key letters concerning the status of recommendations;

- policy statements from the Secretary and the Board;

- Annual Reports to Congress from the Secretary and the Board concerning Board-related matters;

- Resumes of the Board members;

- Department Manual for Interface with the Board; and 
- Board staff issue reports provided to the Department by the Board. 


\section{List of Appendices}

Appendix A Orders and Departmental Safety Directives of Interest to the Board . A-1

Appendix B $\quad$ Site Visits Supported by the Department in $2000 \ldots \ldots \ldots \ldots$. . . . 1

Appendix C Key Department/Board Correspondence in $2000 \ldots \ldots \ldots \ldots$ C-1 


\section{Appendix A \\ Orders and Departmental Safety Directives of Interest to the Board}

This appendix (Table A.1) provides a listing of the orders identified as "of interest" to the Board, and a listing of Departmental safety directives "of interest" to the Board that were changed in 2000, which are given in Table A.1 and Table A.2 respectively.

Table A.1 - Orders of Interest to the Board

\begin{tabular}{|c|c|c|}
\hline Order & Title. & Note \\
\hline 0151.1 & Comprehensive Emergency Management System & 3 \\
\hline 0210.1 & Performance Indicators and Analysis of Operations Information & 3 \\
\hline $\mathrm{O} 225.1 \mathrm{~A}$ & Accident Investigations & 3 \\
\hline O231.1 & Environment, Safety, and Health Reporting & 3 \\
\hline $\mathrm{O} 232.1 \mathrm{~A}$ & Occurrence Reporting and Processing of Operations Information & 3 \\
\hline $\mathrm{O} 251.1 \mathrm{~A}$ & Directives System & 3 \\
\hline 0252.1 & Technical Standards Program & 3 \\
\hline $0360.1 \mathrm{~A}$ & Federal Employee Training & 3 \\
\hline O414.1A & Quality Assurance & 3 \\
\hline O420.1 & Facility Safety & 3 \\
\hline O425.1A & Startup and Restart of Nuclear Facilities & 3 \\
\hline O430.1 & Life Cycle Asset Management & 3 \\
\hline O435.1 & Radioactive Waste Management & 4 \\
\hline O440.1A & Worker Protection Management for DOE Federal and Contractor Employees & 3 \\
\hline P441.1 & Radiological Protection for DOE Activities & 4 \\
\hline O451.1A & National Environmental Policy Act Compliance Program & 3 \\
\hline O452.1A & Nuclear Explosive and Weapon Surety Program & 3 \\
\hline $0452.2 \mathrm{~A}$ & Safety of Nuclear Explosive Operations & 3 \\
\hline O460.1A & Packaging and Transportation Safety & 3 \\
\hline 0460.2 & Departmental Materials Transportation and Packaging Management & 3 \\
\hline O474.1 & Control and Accountability of Nuclear Materials & 1 \\
\hline $01300.2 A$ & DOE Technical Standards Program & 4 \\
\hline O1360.2B & Unclassified Computer Security Program & 1 \\
\hline
\end{tabular}




\begin{tabular}{|c|c|c|}
\hline Order & Title & Note \\
\hline 01540.2 & Hazardous Material Packaging for Transport - Administrative Procedures & 1 \\
\hline O1540.3A & Base Technology for Radioactive Material Transportation Packaging Systems & 1 \\
\hline O3790.1B & Federal Employee Occupational Safety and Health Program & 4 \\
\hline O4330.4B & Maintenance Management Program & 1 \\
\hline O4700.1 & Project Management System & 1 \\
\hline O5000.3B & Occurrence Reporting and Processing of Operations Information & 1 \\
\hline O5400.1 & General Environmentảl Protection Program & 1 \\
\hline O5400.2A & Environmental Compliance Issue Coordination & 1 \\
\hline 05400.3 & Hazardous and Radioactive Mixed Waste Program & 4 \\
\hline O5400.4 & $\begin{array}{l}\text { Comprehensive Environmental Response, Compensation, and Liability Act } \\
\text { Requirements }\end{array}$ & 1 \\
\hline 05400.5 & Radiation Protection of the Public and the Environment & 1 \\
\hline O5440.1E & National Environmental Policy Act Compliance Program & 1 \\
\hline O5480.1B & Environment, Safety and Health Program for DOE Operations & 1 \\
\hline 05480.3 & $\begin{array}{l}\text { Safety Requirements for the Packaging and Transportation of Hazardous } \\
\text { Materials, Hazardous Substances, and Hazardous Wastes }\end{array}$ & 1 \\
\hline 05480.4 & Environment Protection, Safety, and Health Protection Standards & 1 \\
\hline 05480.5 & Safety of Nuclear Facilities & 1 \\
\hline 05480.6 & Safety of Department of Energy-Owned Nuclear Reactors & 1 \\
\hline O5480.7A & Fire Protection & 1 \\
\hline O5480.8A & Contractor Occupational Medical Program & 1 \\
\hline O5480.9A & Construction Safety and Health Program & 1 \\
\hline O5480.10 & Contractor Industrial Hygiene Program & 1 \\
\hline 05480.11 & Radiation Protection for Occupational Workers & 1 \\
\hline O5480.15 & $\begin{array}{l}\text { Department of Energy Laboratory Accreditation Program for Personnel } \\
\text { Dosimetry }\end{array}$ & 1 \\
\hline O5480.17 & Site Safety Representatives & 1 \\
\hline O5480.18 & Environment Safety and Health Program for DOE Operations & \\
\hline
\end{tabular}




\begin{tabular}{|c|c|c|}
\hline Order & Title & Note \\
\hline O5480.18B & Nuclear Facility Training Accreditation Program & 1 \\
\hline 05480.19 & Conduct of Operations Requirements for DOE Facilities & 1 \\
\hline O5480.20A & $\begin{array}{l}\text { Personnel Selection, Qualification, Training and Staffing Requirements at } \\
\text { DOE Reactor and Non-Reactor Nuclear Facilities }\end{array}$ & 1 \\
\hline O5480.21 & Unreviewed Safety Questions & 1 \\
\hline 05480.22 & Technical Safety Requirements & 1 \\
\hline 05480.23 & Nuclear Safety Analysis Reports & 1 \\
\hline 05480.24 & Nuclear Criticality Safety & 1 \\
\hline 05480.25 & Safety of Accelerator Facilities & 1 \\
\hline O5480.26 & $\begin{array}{l}\text { Trending and Analysis of Operations Information Using Performance } \\
\text { Indicators }\end{array}$ & 1 \\
\hline O5480.28 & Natural Phenomena Hazards Mitigation & 1 \\
\hline 05480.29 & Employee Concerns Management System & 1 \\
\hline O5480.30 & Nuclear Reactor Safety Design Criteria & 1 \\
\hline O5480.31 & Startup and Restart of Nuclear Facilities & 1 \\
\hline O5481.1B & Safety Analysis and Review System & 1 \\
\hline O5482.1B & Environment, Safety, and Health Appraisal Program & 1 \\
\hline O5483.1A & $\begin{array}{l}\text { Occupational Safety and Health Program for DOE Contractor Employees at } \\
\text { Government-Owned Contractor-Operated Facilities }\end{array}$ & 1 \\
\hline O5484.1 & $\begin{array}{l}\text { Environmental Protection, Safety and Health Protection Information Reporting } \\
\text { Requirements }\end{array}$ & 1 \\
\hline $05500.1 B$ & Emergency Management System & 1 \\
\hline $05500.2 B$ & Emergency Categories, Classes, and Notification and Reporting Requirements & 1 \\
\hline $05500.3 \mathrm{~A}^{\prime}$ & Planning and Preparedness for Opperational Emergencies & 1 \\
\hline $05500.4 \mathrm{~A}$ & Public Affairs Policy and Planning Requirements for Emergencies & 1 \\
\hline O5500.7B & Emergency Operating Records Protection Program & 1 \\
\hline O5500.10 & Emergency Readiness Assurance Program & 1 \\
\hline O5530.1A & Accident Response Group & 2 \\
\hline O5530.2 & Nuclear Emergency Search Team & 2 \\
\hline
\end{tabular}




\begin{tabular}{|c|c|c|}
\hline Order. & Title & Note \\
\hline 05530.3 & Radiological Assistance Program & 2 \\
\hline O5530.4 & Aerial Measuring System & 2 \\
\hline 05600.1 & $\begin{array}{l}\text { Management of the Department of Energy Weapon Program and Weapon } \\
\text { Complex }\end{array}$ & 2 \\
\hline 05610.10 & Nuclear Explosive and Weapon Safety Program & 2 \\
\hline O5610.11 & Nuclear Explosive Safety & 2 \\
\hline 05610.12 & $\begin{array}{l}\text { Packaging and Offsite Transportation of Nuclear Components, and Special } \\
\text { Assemblies Associated with the Nuclear Explosive and Weapon Safety } \\
\text { Program }\end{array}$ & 2 \\
\hline $05632.1 \mathrm{C}$ & Protection and Control of Safeguards and Security Interests & 1 \\
\hline O5632.11 & Physical Protection of Unclassified Irradiated Reactor Fuel in Transit & 4 \\
\hline $05700.6 \mathrm{C}$ & Quality Assurance & 1 \\
\hline $05820.2 \mathrm{~A}$ & Radioactive Waste Management & 2 \\
\hline O6430.1A & General Design Criteria & 1 \\
\hline $10 \mathrm{CFR} 820$ & Procedural Rules for DOE Nuclear Activities & 3 \\
\hline 10CFR830.110 & Safety Analysis Reports & 3 \\
\hline 10CFR830.112 & Unreviewed Safety Requirements & 3 \\
\hline 10 CFR 830.120 & Quality Assurance Requirements & 3 \\
\hline 10 CFR 830.310 & Conduct of Operations & 3 \\
\hline 10 CFR 830.320 & Technical Safety Requirements & 3 \\
\hline 10 CFR 830.330 & Training and Qualification & 3 \\
\hline 10 CFR 830.340 & Maintenance Management & 3 \\
\hline 10 CFR 830,350 & Operational Occurrence Reporting & 3 \\
\hline 10 CFR 834 & Radiation Protection of the Public and the Environment & 3 \\
\hline 10 CFR 835 & Occupational Radiation Protection & 3 \\
\hline
\end{tabular}

\section{Notes:}

(1) On Board's original list of 51 Orders of Interest; some of these have been canceled but remain in effect in certain contracts. 
(2) Added to Board's list of Orders of Interest with expansion of Board's jurisdiction to include weapons assembly, disassembly, and testing safety.

(3) Added to Board's list due to conversion to three-digit orders and nuclear safety rules.

(4) Other additions based on ongoing Board staff review and evaluation.

Table A.2 - DOE Safety Directives Coordinated with the Board Staff And Issued in 2000

\begin{tabular}{|c|c|c|c|c|}
\hline Directive & Title & Date & $\begin{array}{c}\text { New/ } \\
\text { Revised }\end{array}$ & Comment \\
\hline O 151.1A & $\begin{array}{l}\text { Comprehensive Emergency } \\
\text { Management System }\end{array}$ & $11 / 1 / 00$ & revised & Replaced O 151.1 \\
\hline 0413.3 & $\begin{array}{l}\text { Program and Project Management for } \\
\text { the Acquisition of Capital Assets }\end{array}$ & $10 / 13 / 00$ & new & . \\
\hline 0420.1 & Facility Safety & $11 / 22 / 00$ & revised & Change 003 \\
\hline $0425.1 \mathrm{~B}$ & $\begin{array}{l}\text { Startup and Restart of Nuclear } \\
\text { Facilities }\end{array}$ & $12 / 21 / 00$ & revised & Replaced O 425.1A \\
\hline 0461.1 & $\begin{array}{l}\text { Packaging and Transfer or } \\
\text { Transportation of Materials of National } \\
\text { Security Interest }\end{array}$ & $9 / 29 / 00$ & new & \\
\hline $0470.2 \mathrm{~A}$ & $\begin{array}{l}\text { Security and Emergency Management } \\
\text { Independent Oversight and } \\
\text { Performance Assurance Program }\end{array}$ & $3 / 1 / 00$ & revised & Replaced 0470.2 \\
\hline M 426.1-1 & Federal Technical Capability Manual & $6 / 5 / 00$ & new & \\
\hline M 461.1-1 & $\begin{array}{l}\text { Packaging and Transfer of Materials of } \\
\text { national Security Interest Manual }\end{array}$ & $9 / 29 / 00$ & new & \\
\hline G 420.1-1 & $\begin{array}{l}\text { Nonreactor Nuclear Safety Design } \\
\text { Criteria and Explosives Safety Criteria } \\
\text { Guide for use with DOE O 420.1, } \\
\text { Facility Safety }\end{array}$ & $3 / 28 / 00$ & new & \\
\hline G 420.1-2 & $\begin{array}{l}\text { Guide for the Mitigation of Natural } \\
\text { Phenomena Hazards for Nuclear } \\
\text { Facilities and Nonnuclear Facilitiès }\end{array}$ & $3 / 28 / 00$ & new & \\
\hline STD-1063-00 & Facility Representatives & $3 / 00$ & revised & \\
\hline STD-1136-00 & $\begin{array}{l}\text { Guide of Good practices for } \\
\text { Occupational Radiological Protection } \\
\text { in Uranium Facilities }\end{array}$ & $8 / 00$ & revised & \\
\hline
\end{tabular}




\begin{tabular}{|c|l|l|l|l|}
\hline STD-1137-00 & $\begin{array}{l}\text { Fire Protection Engineering Functional } \\
\text { Area Qualification Standard }\end{array}$ & $7 / 00$ & new & \\
\hline STD-1138-00 & $\begin{array}{l}\text { Industrial Hygiene Functional Area } \\
\text { Qualification Standard }\end{array}$ & $7 / 00$ & new & \\
\hline STD-1139-00 & Chemical Management & $11 / 00$ & new & \\
\hline STD-3003-00 & $\begin{array}{l}\text { Backup Power Sources for DOE } \\
\text { Facilities }\end{array}$ & $1 / 00$ & revised & \\
\hline STD-3006-00 & $\begin{array}{l}\text { Planning and Conduct of Operational } \\
\text { Readiness Reviews (ORR) }\end{array}$ & $6 / 00$ & revised & \\
\hline STD-3013-00 & $\begin{array}{l}\text { Stabilization, Packaging, and Storage } \\
\text { of Plutonium-Bearing Materials }\end{array}$ & $9 / 00$ & revised & \\
\hline STD-3028-00 & $\begin{array}{l}\text { Criteria for Packaging and Storing } \\
\text { Uranium-233 Bearing Materials }\end{array}$ & $7 / 00$ & new & \\
\hline
\end{tabular}




\section{Appendix B \\ Site Visits Supported by the Department in 2000}

\section{Albuquerque}

- On February 7-9, 2000, the Board's staff visited the Albuquerque Operations Office to review safety in project management at the Los Alamos National Laboratory and Dynamic experimentation.

- On April 10-14, 2000, the Board's staff visited to the Albuquerque Operations Office to attend the Weapon Response Working Group Meeting.

- On April 18-21, 2000, the Board's staff visited the Albuquerque Operations Office to review laboratory support of Pantex operations at Building 61.

- On May 24-25, 2000, the Board's staff traveled to the Albuquerque Operations Office to attend the W76 Milestone 3 Meeting.

\section{$\underline{\text { Amarillo }}$}

- On August 7-11,2000, the Board's staff visited the Amarillo Area Office to review Weapons 76 Nuclear Explosive Safety Study.

\section{Fernald Site}

- On April 21, 2000, the Board's staff traveled to the Fernald Site to review Radioactive Waste Packaging Safety.

- On September 18-22, 2000, the Board's staff visited the Fernald Site to review the Safety Management Program.

\section{Hanford}

- On January 10-14, 2000, the Board's staff visited the Hanford Site to review the Plutonium Finishing Plant ISMS Verification, Tank Waste Remediation System, and Privatization Design.

- On January 31-February 4, 2000, the Board's staff visited the Hanford Site to review the Tank Waste Remediation System Privatization Design. 
- On February 7-11, 2000, the Board's staff visited the Hanford Site to review the Tank Waste Remediation System Privatization Design.

- On February 14-18, 2000, the Board's staff visited the Hanford Site to review the Tank Waste Remediation System Privatization Design.

- On March 21-24, 2000, the Board's staff visited the Hanford Site to attend the 94-1 material stabilization and ventilation review at the Plutonium Finishing Plant.

- On April 4-7, 2000, the Board's staff visited the Hanford Site to observe Integrated Safety Management System Phase I Verification for Fluor Hanford Incorporated.

- On April 17-21, 2000, the Board's staff visited the Hanford Site to observe Integrated Safety Management System Phase I Verification for Fluor Hanford Incorporated.

- On May 8-12, 2000, the Board's staff visited the Hanford Site to review the Spent Nuclear Fuel Project Design.

- On May 15-19, 2000, the Board's staff visited the Hanford Site to review the Spent Nuclear Fuel Project.

- On May 22-26, 2000, the Board's staff visited the Hanford Site to observe spent nuclear fuel project design review.

- On June 5-8, 2000, the Board's staff visited the Hanford Site to review Spent Nuclear Fuel Project design and issue closure.

- On June 12-16, 2000, the Board's staff visited the Hanford Site to observe the Fluor Daniel Incorporated and DOE Richland's Phase II ISMS Verification Review.

- On June 26-30, 2000, the Board's staff visited the Hanford Site to review the double shell high level waste tank farm integrity program.

- On July 10-14, 2000, the Board's staff visited the Hanford Site to review the fire protection program.

- On July 17-21, 2000, the Board's staff visited the Hanford Site to review criticality safety.

- On July 17-21, 2000, the Board's staff visited the Hanford Site to review the fire protection program. 
- On July $24-27,2000$, the Board's staff visited the Hanford Site to review criticality safety.

- On August 14-18, 2000, the Board's staff visited the Hanford Site to review worker. protection and work planning.

- On August 21-25, 2000, the Board's staff visited the Hanford Site to observe solution stabilization operational readiness review at the Plutonium Finishing Plant, review worker protection and work planning at K-Basin and Tank Farm, review the spent nuclear fuel project open items and observe contractor operational readiness review.

- On August 28-September 1, 2000, the Board's staff visited the Hanford Site to review worker protection and work planning at K-Basin and Tank Farm.

- On August 28-September 1, 2000, the Board's staff visited the Hanford Site to review spent nuclear fuel project open items and observe contractor operational readiness review.

- On October 2-6, 2000, the Board's staff visited the Hanford Site to review worker protection and work planning.

- On October 10-13, 2000, the Board's staff visited the Hanford Site to review the spent nuclear fuel project design and issue closure.

- On October 30- November 3, 2000, the Board's staff visited the Hanford Site to observe operational readiness reviews for the Spent Nuclear Fuel Project.

- On November 13-17, 2000, the Board's staff visited the Hanford Site to review Decontamination and Decommissioning Activities.

- On November 20, 2000, the Board's staff visited the Hanford Site to review Decontamination and Decommissioning Activities.

- On November 27-December 1, 2000, the Board's staff visited the Hanford Site to observe the operational readiness review for the spent nuclear fuel project.

- On December 4-7, 2000, the Board's staff visited the Hanford Site to attend the Integrated Safety Management Workshop. 
- On December 11-15, 2000, the Board's staff visited the Hanford Site to observe the follow up chemical safety review, and to discuss the Office of River Protection's response to a Board letter regarding the Richland Operations Office Integrated Safety Management System, and Waste Treatment Plant design.

\section{Idaho National Engineering and Environmental Laboratory}

- On January 31-February 4, 2000, the Board's staff visited the Idaho National Engineering and Environmental Laboratory to observe readiness to restart the New Waste Calciner Facility and review ISMS status at the Idaho Nuclear Technologies and Engineering Center.

- On March 20-24, 2000, the Board's staff visited Idaho National Engineering and Environmental Laboratory to observe Integrated Safety Management System Phase II implementation.

- On June 5-9, 2000, the Board's staff visited the Idaho National Engineering and Environmental Laboratory to observe the ISMS Phase II Verification.

- On September 18-22, 2000, the Board's staff visited the Idaho National Engineering Environmental Laboratory to observe readiness to restart High-Level Liquid Waste Evaporator at the Idaho Nuclear Technologies and Engineering Center.

- On November 6-9, 2000, the Board's staff visited the Idaho National Engineering Environmental Laboratory to observe the evaluation of Integrated Safety Management by the Office of Environment, Safety and Health.

\section{Lawrence Livermore National Laboratory}

- On April 18-19, 2000, the Board's staff visited the Lawrence Livermore National Laboratory to observe the mechanical safe and arm detonator surveillance review.

- On May 15-18, 2000, the Board's staff visited the Lawrence Livermore National Laboratory to review the design and authorization basis of defense nuclear facilities.

- On June 19-23, 2000, the Board's staff traveled to the Lawrence Livermore National Laboratory to attend the Technical 24 staff technical exchange and the Department of Energy's explosive safety conference.

- On September 18-22, 2000, the Board's staff visited the Lawrence Livermore National Laboratory to observe the Integrated Safety Management System Verification. 
- On September 27-28, 2000, the Board's staff visited the Lawrence Livermore National Laboratory to review the LLNL Electrical Safety Program, Loss of Power Response, and Electrical Distribution System.

- On November 1-2, 2000, the Board's staff visited the Lawrence Livermore National Laboratory to review the LLNL Chemical Safety Program in defense nuclear facilities.

- . On November 28-30, 2000, the Board's staff visited the Lawrence.Livermore National Laboratory to review the integration of Hazards Analyses.

- On December 6-7, 2000, the Board's staff visited the Lawrence Livermore National Laboratory to review plutonium immobilization technology.

\section{Los Alamos National Laboratory}

- On January 19-21, 2000, the Board's staff visited the Los Alamos National Laboratory to review Defense Programs mission work at the Annular Core Research Reactor and attend the Dynamic Experiments Blue Ribbon Panel Meeting.

- On February 29-March 2, 2000, the Board's staff visited Los Alamos National Laboratory to attend the pit disassembly and conversion facility demonstration.

- On April 10-14, 2000, the Board's staff visited the Los Alamos National Laboratory to review chemical safety and observe the activity-level work planning.

- On May 1-4, 2000, the Board's staff visited the Los Alamos National Laboratory to attend the Project Management Advisory Panel Meeting.

- On May 16-18, 2000, the Board's staff traveled to the Los Alamos National Laboratory to support a Board trip.

- On May 22-26, 2000, the Board's staff visited the Los Alamos National Laboratory to review pit production authorization basis.

- On May 30-June 2, 2000, the Board's staff visited the Los Alamos National Laboratory to observe the Nuclear Material Science and Technology Division Assessment.

- On June 12-15, 2000, the Board's staff visited the Los Alamos National Laboratory to review flooding potential. 


\section{Annual Report to Congress}

- On June 26-28, 2000, the Board's staff visited the Los Alamos National Laboratory for the technical interchange meeting with ESA-WE and the X Division.

- On July 10-14, 2000, the Board's staff visited the Los Alamos National Laboratory to review the design of new facilities and major upgrades, infrastructure development for authorization bases, and flood mitigation activities.

- On September 11-15, 2000, the Board's staff visited the Los Alamos National . Laboratory to support a site visit, review dynamic experiments and observe Integrated Safety Management System Verification.

- On October 23-27, 2000, the Board's staff visited the Los Alamos National Laboratory to review pit manufacturing design and construction, Fire Water Loop and Project Engineering Activities, and attend the Nuclear Criticality Safety Improvement Conference.

\section{Mound Site}

- On April 24-27, 2000, the Board's staff visited the Mound Site to observe the metal tritides readiness assessment.

- On September 18-22, 2000, the Board's staff visited the Mound Site to review the Safety Management Program.

- On September 25-26, 2000, the Board's staff visited the Mound Site to review fire hazard of the Mound Waste Storage Facility.

\section{Miamisburg Site}

- On February 23-25, 2000, the Board's staff visited the Miamisburg Environmental Management Project to discuss metal tritides and organically bound tritium technical basis.

\section{$\underline{\text { Nevada Test Site }}$}

- On March 27-31, 2000, the Board's staff visited the Nevada Test Site to attend the Damaged Nuclear Device Operations review and the National Energy Strategy conference.

- On April 3-7, 2000, the Board's staff visited the Nevada Test Site to review the Integrated Safety Management System Verification. 
- On April 24-27, 2000, the Board's staff visited the Nevada Test Site to observe exercises for the disposition of a damaged nuclear weapon and review Integrated Safety Management System Verification.

- On May 15-19, 2000, the Board's staff visited the Nevada Operations Office to attend Annual Facility Representatives Workshop.

- On May 15-19, 2000, the Board's staff traveled to the Nevada Operations Office to attend the Annual Facility Representatives Workshop.

- On June 19-22, 2000, the Board's staff visited the Nevada Test Site to review disposition of a damaged nuclear weapon at the device assembly facility.

- $\quad$ On August 29-September 1, 2000, the Board's staff visited the Nevada Test Site to review the JASPER project/facility and attend the test readiness seminar.

- On September 11-15, 2000, the Board's staff visited the Nevada Test Site to observe and review the Nevada Integrated Safety Management System Phase II Verification.

- On September 18-22, 2000, the Board's staff visited the Nevada Test Site to review development of capability and observe exercise for disposition of a damaged weapon at the Nevada Test Site and the Device Assembly Facility.

- On November 13-15, 2000, the Board's staff visited the Nevada Test Site to review the U1A Facilities.

- On November 27-December 1, 2000, the Board's staff visited the Nevada Operations Office to attend the Department of Energy Quality Assurance and Price Anderson Act Workshop.

\section{$\underline{\text { Oakland Site }}$}

- On April 4-7, 2000, the Board's staff traveled Oakland Operations Office to attend the Department of Energy's Society for Effective Lessons Learned Sharing Workshop.

\section{Oak Ridge Site}

- On January 19-21, 2000, the Board's staff visited the Oak Ridge Operations Office to discuss the Department's response to a Board letter on Safety Basis for Defense Nuclear Facilities at $\mathrm{Y}-12$. 
- On February 8-10, 2000, the Board's staff visited the Oak Ridge Operations Office to participate in the 97-1 technical team meeting and to discuss the storage standards for uranium-233.

- On February 22-25, 2000, the Board's staff visited the Oak Ridge Operations Office to review criticality safety and attend the design and construction meeting.

- On February 28-March 2, 2000, the Board's staff visited the Oak Ridge Operations Office to review the implementation status of the Emergency Management Action Plan, Y-12 Chemical Safety, and weapon dismantlement.

- On March 14-16, 2000, the Board's staff visited the Oak Ridge Operations Office to attend the 97-1 technical team meeting and review the uranium-233 storage standard.

- On April 4-6, 2000, the Board's staff traveled, to the Oak Ridge Operations Office to support the Board on a site visit.

- On April 11-13, 2000, the Board's staff traveled to the Oak Ridge Operations Office to review the hydrogen fluoride system at Building 9212 at the Y-12 Plant.

- On April 24-26, 2000, the Board's staff visited the Oak Ridge Operations Office to review safety analysis for the new TTU waste treatment and packaging facility.

- On May 1-4, 2000, the Board's staff visited the Oak Ridge Operations Office to discuss the Molten Salt Reactor Experiment activities and review the Uranium-233 Inspection Projects.

- On May 2-4, 2000, the Board's staff visited the Oak Ridge Operations Office to support a Board site visit and observe readiness review.

- On May 15-17, 2000, the Board's staff visited the Oak Ridge Operations Office to review criticality safety and hazard analyses.

- On June 13-14, 2000, the Board's staff traveled to the Oak Ridge Operations Office to attend the Emergency Management Lessons Learned Forum.

- On June 27-29, 2000, the Board's staff visited the Oak Ridge Operations Office to observe the Y-12 fire protection appraisal. 
- On July 11-14, 2000, the Board's staff visited the Oak Ridge Operations Office to observe the 80\% design review for Foster Wheeler Environmental Corporation transuranic waste facility.

- On July 18-21, 2000, the Board's staff visited the Oak Ridge Operations Office to review hydrogen fluoride systems and high enriched uranium materials facility.

- On August 21-25, 2000, the Board's staff visited the Oak Ridge Operations Office to observe the Integrated Safety Management System Phase II Verification.

- On August 28-31, 2000, the Board's staff visited the Oak Ridge Operations Office to review the Integrated Safety Management Phase II Verification for Building 3019.

- On September 5-8, 2000, the Board's staff visited the Oak Ridge Operations Office to follow upon the dismantlement review and review Building 9206 and the Y-12 Plant decontamination and decommissioning activities.

- On October 10-13, 2000, the Board's staff visited the Oak Ridge Operations Office to review Chemical Safety at the Y-12 Plant.

- On October 24-26, 2000, the Board's staff visited the Oak Ridge Operations Office to review the final design for the Foster-Wheeler Environmental Corporation Transuranic Waste Facility.

- On November 7-9, 2000, the Board's staff visited the Oak Ridge Operations Office to review the status of reduction and disassembly issues.

- On November 13-14, 2000, the Board's staff visited the Oak Ridge Operations Office to attend the 97-1 technical team meeting to revise the Program Execution Plan and program direction.

- On November 20-22, 2000, the Board's staff visited the Oak Ridge Operations Office to review the status of fire protection and life safety systems at the Y-12 Plant.

- On November 29-December 1, 2000, the Board's staff visited the Oak Ridge Operations Office to review the electrical safety program. 


\section{$\underline{\text { Pantex Plant }}$}

- On January 4-7, 2000, the Board's staff visited the Pantex Site to observe W-62 initial startup.

- On January 5-7, 2000, the Board's staff contractor visited the Pantex Site to observe the W62 Disassembly and Inspection first production unit.

- On January 10-14, 2000, the Board's staff and staff contractor visited the Pantex Site to observe the Lightning Justification for Continued Operations Readiness Assessment and the W62 Disassembly and Inspection first production unit.

- On January 11-14, 2000, the Board's staff visited the Pantex Site to observe W-62 initial startup.

- On February 1-3, 2000, the Board's staff visited the Pantex Site to review the Fire Protection Program.

- On February 1-4, 2000, the Board's staff visited the Pantex Site to observe the fire protection program review.

- On February 7-11, 2000, the Board's staff visited the Pantex Site to support a Board visit.

- On February 8-10, 2000, the Board's staff visited the Pantex Site to review site specific DNFSB recommendations, actions to address lightning issues, actions to improve the Readiness Review process, review pit repackaging and weapon program work activities and conduct a public meeting.

- On February 22-24, 2000, the Board's staff visited the Pantex Site to review Weapon Systems Tooling Review: Design, Configuration Management, and Training and Qualification.

- On February 22-25, 2000, the Board's staff visited the Pantex Site to review tooling design and configuration management.

- On February 29-March 3, 2000, the Board's staff visited the Pantex Site to observe the Integrated Safety Management System Verification. 
- On March 3, 2000, the Board's staff visited the Pantex Site to review the implementation status of W76/W88 program hazards analyses and controls identification.

- On March 6-9, 2000, the Board's staff visited the Pantex Site to review the implementation status of W761 W88 program hazards analyses and controls identification.

- On March 7-9, 2000, the Board's staff visited the Pantex Site to review W76/W88 safety bases, for staff discussions on recommendation 98-2 and observe the DOE Integrated Safety Management Validation Team Orientation.

- On March 7-10, 2000, the Board's staff visited the Pantex Site to observe the Integrated Safety Management System Verification planning.

- On March 7-8, 2000, the Board's staff visited the Pantex Site to discuss the 98-2 implementation plan.

- On March 13-17, 2000, the Board's staff contractor visited the Pantex Site to review the site-wide exercise, Dust Devil.

- On March 22-23, 2000, the Board's staff visited the Pantex Site to review the Electrical Safety Program at Pantex, Loss of Power Response at Pantex, the Lightning Protection Basis for Interim (operations and attend the Pit Management Team and Pit Thermal meetings.

- On March 22-24, 2000, the Board's staff visited the Pantex Site to review electrical safety.

- On April 4-7, 2000, the Board's staff visited the Pantex Site to review the Integrated Safety Management Validation.

- On April 17-20, 2000, the Board's staff contractor visited the Pantex Site to observe the DOE-AL Readiness Review training.

- On April 24-27, 2000, the Board's staff visited the Pantex Site to review the design of the assembly cell.

- On April 25-26, 2000, the Board's staff visited the Pantex Site to review cell design features. 
- On May 15-16, 2000, the Board's staff visited the Pantex Site to discuss a proposed revision to recommendation 98-2 implementation plan.

- On May 22-26, 2000, the Board's staff visited the Pantex Site to observe the DOE-AL Packaging and Transportation Appraisal.

- On May 22-26, 2000, the Board's staff visited the Pantex Site to review packaging and transportation appraisal of the Amarillo Area Office and the Mason and Hanger Corporation compliance with applicable requirements safety basis review and the BIO upgrade transportation module.

- On May 26- June 2, 2000, a Board's contractor staff visited the Pantex Site to observe the AB Upgrade Program Review.

- On June 12-16, 2000, the Board's staff visited the Pantex Site to review the B61 Nuclear Explosive Safety Study and Readiness Assessment.

- On June 13-16, 2000, the Board's staff visited the Pantex Site to observe the B61, Mod 10, Project activities.

- On June 19-23, 2000, the Board's staff visited the Pantex Site to attend the Weapons 76 Milestone 3 meeting, and observe the Phase II ISMS Verification.

- On June 19-23, 2000, the Board's staff and contractor staff visited the Pantex Site to observe the DOE Integrated Safety Management Validation.

- On June 26-30, 2000, the Board's staff visited the Pantex Site for site familiarization, observe weapons operations, discuss fire hazards analysis/fire safety analysis processes, observing the Integrated Safety Management Validation, to attend the pit management meeting and observe pit repackaging operations.

- On June 28-29, 2000, the Board's staff visited the Pantex Site to review the implementation of recommendation 99-1.

- On July 31- August 4, 2000, the Board's staff visited the Pantex Site to observe: the Lightning Protection Master Study, the DOE Lightning Protection Readiness Assessment and the W76 Nuclear Explosive Safety Study (NESS).

- On August 7-11, 2000, the Board's contractor staff visited the Pantex Site to observe the DOE W76 Readiness Assessment and to observe the W76 Nuclear Explosive Safety Study (NESS). 
- On August 14-18, 2000, the Board's contractor staff visited the Pantex Site to observe the DOE W76 Readiness Assessment and to observe the W76 Nuclear Explosive Safety Study (NESS).

- On August $21-25,2000$, the Board's contractor staff visited the Pantex Site to observe the W76 Nuclear Explosive Safety Study (NESS).

- On August 25-September 1, 2000, the Board's staff and contractor staff visited the Pantex Site to observe the site emergency exercise.

- On August 28-September 1, 2000, the Board's staff visited the Pantex Site to review the Pantex emergency management program, and the lightning protection nuclear explosive safety master study program.

- On September 5-7, 2000, the Board's staff visited the Pantex Site to review fire protection controls associated with W76 Disassembly and Inspection.

- On September 6-8, 2000, the Board's staff visited the Pantex Site to review implementation of fire protection controls for the W76 program.

- On October 3-6, 2000, the Board's staff visited the Pantex Site to review pit storage and authorization basis of building 12-104A and attend the Pit Management Meeting.

- On October 4-6, 2000, the Board's staff visited the Pantex Site to attend the pit management meeting, observe ongoing Nuclear Explosive Operations and review Authorization Bases at Buildings 12-104 \& 12-41.

- On October 16-19, 2000, the Board's staff visited the Pantex Site to review the new W88 authorization basis and its implementation.

- On November 6-9, 2000, the Board's staff and contractor staff visited the Pantex Site to observe the revalidation of the W88 Nuclear Explosive Safety Study (NESS).

- On November 13-17, 2000, the Board's staff visited the Pantex Site to observe the revalidation of the W88 Nuclear Explosive Safety Study (NESS) and the W88 DOE readiness assessment.

- On November 27-December 1, 2000, the Board's staff and contractor staff visited the Pantex Site to observe the revalidation of the W88 Nuclear Explosive Safety Study (NESS) and the W88 DOE readiness assessment. 
- . On December 4-8, 2000, the Board's staff visited the Pantex Site to observe the revalidation of the W88 Nuclear Explosive Safety Study (NESS) and observe the NESS for changes to W87 lightning protection controls.

- On December 11-15, 2000, the Board's staff visited the Pantex Site to attend the DP-20 review of the Pantex Fiscal Year 01 performance priorities, to review W78 Step 1 Process issues and W87 lightning protection control changes.

- On December 12-14, 2000, the Board's staff visited the Pantex Site to review W88 Nuclear Explosive Safety Study and DOE Readiness Assessment.

\section{Rocky Flats}

- On February 29-March 3, 2000, the Board's staff visited Rocky Flats to review the Plutonium Stabilization and Packaging System, Phase II Inner Tent Chamber, and the Integrated Work Control Program process.

- On April 3-6, 2000, the Board's staff visited Rocky Flats to discuss fire protection topics.

- On April 10-13, 2000, the Board's staff visited Rocky Flats to review fire protection program elements.

- On May 1-4, 2000, the Board's staff visited Rocky Flats to review criticality safety.

- On August 29-31, 2000, the Board's staff visited Rocky Flats for a general site review.

- . On September 11-13, 2000, the Board's staff visited Rocky Flats to attend the Federal Technical Capability Panel Meeting.

- On September 19-21, 2000, the Board's staff visited Rocky Flats to review the Integrated Work Control Program, Plutonium Stabilization and Packaging Systems, and the Inner Tent Chamber.

\section{Sandia National Laboratory}

- On January 19-21, 2000, the Board's staff visited the Sandia National Laboratory to review Defense Programs mission work at the Annular Core Research Reactor and attend the Dynamic Experiments Blue Ribbon Panel Meeting. 
- On May 16-18, 2000, the Board's staff traveled to the Sandia National Laboratory to support a Board trip.

- On July 10-14, 2000, the Board's staff visited the Sandia National Laboratory to attend briefings on Technical Report 24 and review aging high explosive and high explosive components.

- On November 13-17, 2000, the Board's staff visited the Sandia National Laboratories to review operational readiness of gamma irradiation facility.

\section{Savannah River Site}

- In February 7-10, 2000, the Board's staff visited the Savannah River Operations Office to review criticality controls.

- On February $15-17,2000$, the Board's staff visited the Savannah River Operations Office to review H-Canyon Phase 3 restart preparations.

- $\quad$ On February 29-March 2, 2000, the Board's staff visited the Savannah River Operations Office to review $\mathrm{H}$-Canyon Phase 3 restart preparations.

- On March 8-10, 2000, the Board's staff visited the-Savannah River Operations Office to review the Tank 8 sludge removal project.

- On March 20-24, 2000, the Board's staff visited the Savannah River Operations Office to attend the Radiation Worker II Training session.

- On March 20-22, 2000, the Board's staff visited the Savannah River Operations Office to attend the High Level Waste Tank Space Management process.

- On March 28-30, 2000, the Board's staff visited the Savannah River Operations Office to review the FB-Line.

- On April 17-20, 2000, the Board's staff traveled to the Savannah River Operations Office to support the Board on a site visit.

- On April 24-28, 2000, the Board's staff traveled to the Savannah River Operations Office to review the design of the confinement ventilation system and remote handling of the tritium extraction facility. 
- On May 23-25, 2000, the Board's staff visited the Savannah River Operations Office to discuss Tank Waste Remediation System process, Research and Development, and High-Level Waste Issues.

- On June 12-16, 2000, the Board's staff visited the Savannah River Operations Office to review the high level radioactive waste facility, replacement high level waste evaporator tank 8, L-Experiment Facility, and to observe the remote handling building design review and review the requirement implementation matrix at the tritium extraction facility.

- On June 19-21, 2000, the Board's staff visited the Savannah River Operations Office to observe the remote handling building design review, and review the requirement implementation matrix at the tritium extraction facility.

- On June 26-27, 2000, the Board's staff visited the Savannah River Operations Office to review tritium.

- On June 27-29, 2000, the Board's staff visited the Savannah River Operations Office to review the americium/curium project.

- On July 10-14, 2000, the Board's staff visited the Savannah River Operations Office to observe the tritium extraction facility structural design review of the remote handling building, melt and dilute design, and independent design of L-Experimental Facility Review.

- On July 18-21, 2000, the Board's staff visited the Savannah River Operations Office for an independent review of the L-Experimental Facility and review the design of meltdilute projects.

- On July 25-28, 2000, the Board's staff visited the Savannah River Operations Office for the dismantlement review.

- On August 1-3, 2000, the Board's staff visited the Savannah River Operations Office to observe the Facility Disposition Planning process.

- On August 30-31, 2000, the Board's staff visited the Savannah River Operations Office to review application of the American society of Mechanical Engineers Code for Dynex.

- On September 6-8, 2000, the Board's staff visited the Savannah River Operations Office to review plutonium facilities. 
- On September 25-26, 2000, the Board's staff visited the Savannah River Operations Office for a structural and seismic review.

- On September 27-29, 2000, the Board's staff visited the Savannah River Operations Office to review remaining issues at the Tritium Extraction Facility remote handling building.

- On October 3-6, 2000, the Board's staff visited the Savannah River Operations Office to review the Tritium Extraction Facility design work.

- On October 18-20, 2000, the Board's staff visited the Savannah River Operations Office to review Tank 49 Alt-Salt, and Tank Space Management.

- On October 31-November 3, 2000, the Board's staff visited the Savannah River Site to review the safety aspects of the design of L-Area Experimental Facility.

- On November 28-December 1, 2000, the Board's staff visited the Savannah River Operations Office to accompany the Board on a site visit, and attend the public meeting.

- On December 20-21, 2000, the Board's staff visited the Savannah River Operations Office to review the Electrical Safety Program.

\section{Waste Isolation Pilot Plant}

- On March 12-14, 2000, the Board's staff visited the Waste Isolation Pilot Plant to attend the Remote-Handled Transuranic Waste project meeting.

- On June 20-23, 2000, the Board's staff visited the Waste Isolation Pilot Plant to review facility mods progress in support of remote handled transuranic waste, and preparations to receive contact handled transuranic waste.

\section{West Valley}

- On October 16-19, 2000, the Board's staff traveled to West Valley to attend the Annual Department of Energy High Level Waste Tank Closure Conference. 
$\underline{\text { MISC }}$

- On June 5-9, 2000, the Board's staff traveled to Kings Bay to attend the Tritium Focus Group Meeting.

- On June 26-30, 2000, the Board's staff traveled to Denver to attend the American Radiation Safety Conference.

- On July 10-14, 2000, the Board's staff traveled to Santa Fe to attend the Plutonium Science Conference.

- On August 14-16, 2000, the Board's staff traveled to Knoxville to attend the waste generators meeting on Waste Isolation Pilot Plant remote handling waste acceptance criteria and waste acceptance plan at the Foster-Wheeler Environmental Corporation.

- On October 30-November 1, 2000, the Board's staff traveled to Atlanta to attend the Annual Tank Integrity Workshop.

- On October 31-November 3, 2000, the Board's staff traveled to the Nevada Support Facility to attend the Department's Radiological Control Coordinating Meeting.

- On November 13-16, 2000, the Board's staff traveled to Las Vegas to review current (and projected following upgrades) worker safety status of UIA facility with emphasis on ventilation, emergency egress, and electrical power supply.

- On November 13-16, 2000, the Board's staff traveled to Los Angeles to attend the $\mathrm{A} / \mathrm{ChE}$ training for engineering design and process safety. 


\section{Appendix C \\ Key Department/Board Correspondence in 2000}

\section{From the Board to the Department:}

- On January 11, 2000, the Board forwarded a letter to the Assistant Secretary for Environmental Management enclosing a staff issue report documenting observations concerning the Department's upgrade of the work planning process at INEEL per the Integrated System Management System.

- On January 11, 2000, the Board forwarded a letter to the Acting Assistant Secretary for Defense Programs enclosing a staff issue report on lightning protection for Nuclear Explosive operations at the Pantex Site.

- On January 13,2000, the Board forwarded a letter to the Assistant Secretary for Environment, Safety and Health reporting resolution of comments on proposed guidance to DOE-STD-3009-94, and on the draft Implementation Guides DOE G 420.1-X and DOE G 420.1-Y.

- On January 13, 2000, the Board forwarded a letter to the Acting Assistant Secretary for Defense Programs forwarding a revised Staff Issue Report on the In-Progress Review of the W79 Dismantlement Program.

- On January 14, 2000, the Board forwarded a letter to the Acting Assistant Secretary for Defense Programs forwarding a staff issue report on the Uranium-233 Inspection Program at Oak Ridge National Laboratory.

- On January 14,2000 , the Board forwarded a letter to the Secretary providing Recommendation 2000-1, Stabilization and Storage of Nuclear Material.

- On January 14,2000 , the Board forwarded a letter to the Deputy Secretary commending the Rocky Flats Field Office in citing its contractor for inadequate implementation of Technical Safety Requirements and Operational Safety Requirements.

- On January 20,2000, the Board forwarded a letter to the Secretary announcing this year's Stell Safety Leadership Awardee - Mr. Joseph F. King from the Office of Defense Programs. It also recognizes and commends Mr. Frank R. McCoy III, Dr. Bruce Matthews, Mr. Richard M. Stark, Mr. Mark B. Whitaker, Jr., and Ms. Ellen LivingstonBehan for their exemplary performance and contributions in their respective assignments. 
- On January 24, 2000, the Board announced a public hearing scheduled for February 9 , 2000, 6:00 pm, at the Ambassador Hotel, in Amarillo, Texas regarding matters affecting health and safety at Pantex.

- On February 7, 2000, the Board forwarded a letter to the Assistant Secretary for Environmental Management enclosing a staff issue report regarding the distributed control system used to operate the Defense Waste Processing Facility at the Savannah River Site.

- On February 14, 2000, the Board's Technical Director sent a letter to the President of Westinghouse Savannah River Company commending the outstanding performance of the instructors relative to the Radiation Worker II and Consolidated Annual Training for the Board's technical staff held on January 19-20, 2000.

- On February 29, 2000, the Board sent a letter to the Assistant Secretary for Environmental Management regarding the quality of information provided to the Board on the Integrated Water Treatment System at Hanford.

- On February 29, 2000, the Board sent a letter commending Mr. Frank R. McCoy III, on his retirement from the Department after many years of dedicated service.

- On March 2, 2000, the Board sent a letter to the Deputy Secretary forwarding a staff issue report on the authorization basis quality review at the Los Alamos National Laboratory.

- On March 3, 2000, the Board forwarded its Tenth Annual Report to Congress for calendar year 1999 .

- On March 7, 2000, the Board sent a letter to the Secretary encouraging the Department's support of the expanded research programs of the Offices of Science (SC) and Environmental Management (EM) on the assessment of health risks from exposure to low levels of radiation.

- On March 7, 2000, the Board sent a letter forwarding a staff issue report on the review of chemical safety aspects of handling and packaging radioactive waste in Fernald Environmental Management Project.

- On March 8, 2000, the Board forwarded a letter to the Deputy Secretary regarding Order 425.1A, Startup and Restart of Nuclear Facilities and a staff issue report on the review status of W62 Disassembly and Inspection Program at Pantex. 
- On March 8, 2000, the Board sent a letter forwarding Recommendation 2000-2, Configuration Management, Vital Safety Systems.

- On March 8, 2000, the Board forwarded Technical Report 26, Improving Operation and Performance of Confinement Ventilation Systems at Hazardous Facilities of the Department of Energy.

- On March 9, 2000, the Board forwarded a staff issue report on the K-Area Material Storage project at the Savannah River Site.

- On March 23, 2000, the Board forwarded a letter to the Assistant Secretary for Environmental Management enclosing a staff issue report documenting observations concerning the Department's Integrated Safety Management Phase I/II Verification Review at Hanford's Plutonium Finishing Plant.

- On March 29, 2000, the Board forwarded a letter to the Acting Deputy Administrator for Defense Programs enclosing a staff issue report documenting observations concerning the Department's Fire Protection Program at the Pantex Plant.

- On March 30, 2000, the Board forwarded a letter to the Acting Deputy Administrator for Defense Programs enclosing a staff issue report highlighting some issues that require attention concerning the Instrumentation and Control for the Hydrogen Fluoride Supply System at the Oak Ridge Y-12 Plant.

- On April 7, 2000, the Board forwarded a letter to the Secretary accepting the Department's implementation plan for recommendation 99-1.

- On April 2:1, 2000, the Board forwarded a copy of a letter to Mr. Don Moniak, Program Director for Serious Texans Against Nuclear Dumping, regarding his letter of February 9, 2000, providing comments and questions resulting from a Board Public Meeting in Amarillo, Texas.

- On April 25, 2000, the Board forwarded a letter to the Assistant Secretary for Environmental Management, enclosing a staff issue report on Plutonium Stabilization and Packaging System at the Rocky Flats Environmental Technology Site.

- On April 25, 2000, the Board forwarded a letter to the Assistant Secretary for Environmental Management, enclosing a staff issue report on the Integrated Work Control Program at the Rocky Flats Environmental Technology Site. 
- On May 2, 2000, the Board forwarded a letter to the Acting Deputy Administrator for Defense Programs, enclosing a staff issue report which documents a review of the fire hazard analysis for the W76 weapon system disassembly and inspection program. The Board requests a report and briefing within 4 weeks followed by another report and corrective action plan within 60 days.

- On May 11, 2000, the Board forwarded a public meeting announcement regarding Recommendations 95-2 and 98-1, scheduled for May 31, 2000, at 9:00 am, Board's Public Hearing Room, in Washington, DC.

- On May 15, 2000, the Board forwarded a copy of a letter to Mr. LeRoy Moore, Ph. D., Rocky Mountain Peace and Justice Center, regarding his letter of April 24, 2000, addressing plutonium-bearing material being prepared for shipment from the Rocky Flats Environmental Technology Site to the Savannah River Site and to the Waste Isolation Pilot Plant.

- On May 15, 2000, the Board forwarded a letter to the Acting Deputy Administrator for Defense Programs, enclosing staff issue reports which document reviews performed at the Oak Ridge Y-12 Plant on the Enriched Uranium Operations furnaces, safety bases, Building 9206 hazard reduction, and emergency management.

- On May 23, 2000, the Board forwarded a letter to the Secretary suggesting language to be incorporated in upcoming contracts which would standardize the wording that encompasses the enforceable measures required of contractors to ensure health and safety of the public and the workers.

- . On May 23, 2000, the Board forwarded a letter to the Assistant Secretary for Environmental Management, enclosing a staff issue report which documents issues reviewed by the staff regarding high-level waste system at the Savannah River Site.

- On May 23, 2000, the Board forwarded a copy of a letter to Ms. Karen Patterson, Chair, Savannah River Site Citizens Advisory Board (CAB), regarding a request issued by the $\mathrm{CAB}$, to be updated when the Board accepts or rejects the 2000-1 implementation plan.

- On May 23, 2000, the Board forwarded a letter to the Assistant Secretary for Environmental Management, enclosing a staff issue report which documents a review concerning recovery actions and restart planning at the FB-Line facility at the Savannah River Site. 
- On May 23, 2000, the Board forwarded a letter to the Acting Deputy Administrator for Defense Programs, enclosing a staff issue report summarizing the results of a review by the Board staff in support of the Board's recommendation.98-2 at the Pantex Plant.

- On May 23, 2000, the Board forwarded a status report on the impact of Cerro Grand Fire on the Los Alamos National Laboratory.

- On May 24, 2000, the Board forwarded a letter to the Acting Deputy Administrator for Defense Programs; enclosing a staff issue report describing recovery plans for the Los Alamos National Laboratory from the Cerro Grande Fire.

- On May 25, 2000, the Board forwarded a letter to the Deputy Secretary, enclosing a staff issue report by the Board's staff on a recent meeting of the DOE Society for Effective Lessons Learned Sharing.

- On May 30, 2000, the Board forwarded a letter to the Acting Deputy Administrator for Defense Programs, regarding the design of the hydrogen fluoride supply system at the Oak Ridge Y-12 Plant.

- On June 7, 2000, the Board forwarded a letter to the Acting Deputy Administrator for Defense Nuclear Nonproliferation, suggesting use of sand filters as opposed to banks of HEPA filters as the final barrier to airborne release of hazardous and radioactive materials to the environment at the pit disassembly and conversion facility planned for the Savannah River Site.

- On June 13,2000, the Board forwarded a letter to the Assistant Secretary for Environmental Management, enclosing a staff issue report on the Rocky Flats Environmental Technology Site's implementation of DOE Order 435.1, Radioactive Waste Management.

- On June 14, 2000, the Board forwarded a letter to the Secretary enclosing Technical Report 27, regarding Fire Protection at Defense Nuclear Facilities.

- On June 26, 2000, the Board forwarded a letter to the Acting Deputy Administrator for Defense Programs, enclosing a staff issue report on the status of authorization bases at the Lawrence Livermore National Laboratory.

- On June 29, 2000, the Board forwarded a letter to the Assistant Secretary for Environmental Management, enclosing a staff issue report on the review of safety controls for Tank 8 Waste Mobilization at the Savannah River Site. 
- On June 30, 2000, the Board forwarded a letter to the Deputy Secretary accepting closure of recommendation 93-3.

- On July 7, 2000, the Board forwarded a letter to the Secretary regarding budget concerns that may preclude the Department from meeting its commitments per the 99-1 implementation plan.

- On July 10, 2000, the Board forwarded a letter to the Deputy Secretary offering counsel on the role of the Office of Environment, Safety and Health (EH) in implementing Integrated Safety Management.

- On July 10, 2000, the Board forwarded a letter to the Acting Deputy Administrator for Defense Programs, enclosing a staff issue report on the review of worker protection at the Los Alamos National Laboratory.

- On July 10, 2000, the Board forwarded a letter to the Assistant Secretary for Environmental Management, enclosing a staff issue report on the review of the equipment design and safety analysis for remediation work at the Molten Salt Reactor Experiment (MSRE).

- On July 10, 2000, the Board forwarded a letter to the Secretary enclosing a memorandum which describes observations made by members of the Board staff during a site visit to review issues associated with procurement and field testing of high efficiency particulate air (HFPA) at the Hanford site.

- On July 14,2000 , the Board forwarded a letter to the Secretary enclosing its views on specific components of the Department's implementation plan for recommendations 941 and 2000-1, and partially accepting the implementation plan.

- On July 20,2000, the Board forwarded a letter to the Director of the Safety Management Implementation Team, establishing a 45-day reporting requirement to answer additional questions resulting from the May 31, 2000 public meeting on recommendations 95-2 and 98-1.

- On July 20, 2000, the Board forwarded a letter to the Deputy Administrator for Defense Programs, accepting the Department's proposal to delay the report and briefing on fire hazards associated with the W76 Program at the Pantex Plant.

- On August 18,2000, the Board forwarded a letter to the Administrator of the National Nuclear Security Administration, enclosing a staff issue report regarding the review of the Fire Protection Program at the Y-12 Plant. 
- On August 18,2000, the Board forwarded a letter to the Assistant Secretary for Environmental Management, enclosing a staff issue report on the americium/curium $(\mathrm{Am} / \mathrm{Cm})$ solution stabilization project at the Savannah River Site.

- On August 29, 2000, the Board forwarded a letter.to the Deputy Secretary regarding the final version of the Department's standard for long-term storage of uranium-233, per the 97-1 implementation plan.

- On August 29, 2000, the Board forwarded a letter to the Deputy Administrator for Defense Programs, enclosing a staff issue report on flood mitigation measures at the Los Alamos National Laboratory.

- On August 29, 2000, the Board forwarded a letter to the Deputy Administrator for Defense Programs, enclosing a staff issue report on a follow-up technical exchange concerning DNFSB/TECH-24, Safe Handling of Insensitive High Explosive Weapon Subassemblies at the Pantex Plant.

- On August 29, 2000, the Board forwarded a letter to the Assistant Secretary for Environmental Management, establishing a 90-day reporting requirement identifying actions that will be taken to address issues in the enclosed staff issue report on the HighLevel Waste Tank Integrity Program at the Hanford Site.

- On August 30, 2000, the Board forwarded a letter to the Administrator of the National Nuclear Security Administration, enclosing a staff issue report on readiness to resume reduction process for Enriched Uranium Operations.

- On September 8, 2000, the Board forwarded a letter announcing the assignment of David J. Grover to succeed Steve Stokes as one of the two Board Site Representatives at the Department's Hanford Site.

- On September 8, 2000, the Board forwarded a letter to the Secretary enclosing an amplification on Recommendation 2000-2.

- On September 20, 2000, the Board forwarded a letter to the Assistant Secretary for Environmental Management letter requesting the Department to respond to issues summarized in the enclosed staff issue report on technical issues associated with the Spent Nuclear Fuel Project, Hanford Site.

- On September 21, 2000, the Board forwarded a letter to the Under Secretary commending the Department on its two-volume set regarding Vadose Zone: Science and Technology Solutions. 
- On September 26, 2000, the Board forwarded a letter to the Secretary commending the Department of its initiative to assess the defense nuclear facilities, complex-wide, the state of its readiness and capabilities to deal with fires, both occurring off-site and onsite. The Board also reminded the Department of its commitment to forward its plan regarding the 2000-2 recommendation.

- On October 23, 2000, the Board forwarded a letter to the Secretary responding a Department letter dated September 27, 2000, regarding a report on several completed commitments per the 2000-1 implementation plan.

- On October 23, 2000, the Board forwarded a letter to the Deputy Secretary responding to a Department report on Quality Assurance for Safety-Related Software at Defense Nuclear Facilities.

- On October 23, 2000, the Board forwarded a letter to the Deputy Administrator for Defense Programs establishing a 30-day reporting requirement outlining the path forward and schedule for addressing the issues in the enclosed staff report on the implementation of the Lightning Basis for Interim Operation.

- On October 23, 2000, the Board forwarded a letter to the Secretary requesting documentation and a briefing relative to the revised 98-2 implementation plan.

- On October 31;2000, the Board forwarded a letter to the Administrator of the National Nuclear Security Administration enclosing a staff issue report on Integrated Safety Management System Phase II Verification at the Y-12 Plant.

- On October 31, 2000, the Board forwarded a letter to the Deputy Administrator for Defense Programs enclosing a staff issue report on the deactivation and risk reduction activities at Building 9206 at the Y-12 Plant.

- On November 1, 2000, the Board forwarded a letter to the Assistant Secretary for Environmental, Safety and Health relative to the use of the Department's standards, guides, and handbooks to identify and classify safety structures, systems, and components (SSCs) of Defense Nuclear Facilities.

- On November 1, 2000, the Board forwarded a letter to the Assistant Secretary for Environment, Safety and Health regarding the use of the Department's standards, guides, and handbooks to identify and classify safety structures, systems, and components (SSCs) of defense nuclear facilities. 
- On November 7, 2000, the Board forwarded a letter to the Secretary enclosing Board/Tech 28, Safety Basis Expectations for existing Department of Energy Defense Nuclear Facilities and Activities.

- On November 9, 2000, the Board forwarded a public hearing announcement scheduled for November 30, 2000, at the Conference Center in Aiken, South Carolina.

- On November 14, 2000, the Board forwarded a letter to the.Deputy Secretary enclosing a staff issue report on the Department's Integrated Nuclear Materials Management Plan.

- On December 5-6, 2000, Board Member Joseph J. DiNunno gave remarks at the Integrated Safety Management (ISM) 2000 Workshop held in Pasco, Washington.

- On December 14, 2000, the Board forwarded a letter to the Secretary accepting the Department's 2000-2 implementation plan predicated on the assumption that adequate funding will be provided to execute commitments therein.

- On December 14, 2000, the Board forwarded a letter to the Secretary regarding the Integrated Safety Management Workshop held in Richland, Washington.

- On December 15, 2000, the Board forwarded a letter to the Deputy Administrator for Defense Programs regarding efforts to startup certain dynamic experiments at the Los Alamos National Laboratory.

\section{From the Department to the Board:}

- On January 12, 2000, the Assistant Secretary for Environment, Safety and Health sent a letter to the Board reporting the status of the Department's commitment to examine the issue of exchange of information concerning ventilation filtration technology and the 26th Nuclear Air Cleaning conference which is scheduled for September 2000.

- On January 12,2000 , the Secretary sent a letter to the Board congratulating Board Member Dr. Herbert J. C. Kouts on his retirement from government service.

- On January 18,2000 , the Director, Safety Management Implementation Team sent a letter to the Board enclosing the Department's plan for reviewing the effectiveness of the corrective action process under commitment 5.1.3 per the 98-1 implementation plan.

- On February 1,2000, the Secretary sent a letter to the Board forwarding the implementation plan for Board recommendation 99-1. 


\section{Annual Report to Congress}

- On February 1, 2000, the Secretary sent a letter to the Board forwarding the implementation plan, revision 2, for Board recommendation 94-1.

- On February 2, 2000, the Deputy Secretary sent a letter to the Board responding to a letter suggesting the Department review the established contractual arrangements with the Center for Chemical Process Safety (CCPS) and the Institute for Nuclear Power Operations (INPO) with a view toward more effective utilization of each.

- On February 7, 2000, the Albuquerque Operations Office Manager sent a letter to the Board regarding deliverables in the recommendation 98-2 implementation plan.

- On February 9, 2000, the Savannah River Operations Office Manager sent a letter to the Board enclosing the Type B Accident Investigation Board's report regarding intakes of plutonium that occurred at the FB-Line facility on September 1, 1999.

- On February 9, 2000, the Deputy Secretary sent a letter to the Board responding to a letter dated January 20,2000. The response assigns John Gilligan, Chief Information Officer, as the lead for the requested software quality assurance report.

- On February 9, 2000, the Assistant Secretary for Environmental Management sent a letter to the Board regarding the ventilation system in Oak Ridge National Laboratory facilities used for uranium-233 operations and long term storage.

- On February 16, 2000, the Deputy Assistant Secretary for Integration and Disposition, Office of Environmental Management, sent a letter to the Board reporting completion of a Hanford polycubes stabilization commitment per the 94-1 implementation plan.

- $\quad$ On February 23, 2000, the Deputy Assistant Secretary for Military Application and Stockpile Operations in the Office of Defense Programs, sent a letter to the Board forwarding the amended Work Authorization Directive (WAD) for pit repackaging at the Pantex Plant which is a deliverable under the 99-1 implementation plan.

- On February 29, 2000, the Assistant Secretary for Environmental Management, sent a letter to the Board responding to a Board letter dated December 1, 1999 in relation to issues on hazard identification and analysis at the Hanford 233-S Plutonium Concentration Facility.

- On February 29, 2000, the Deputy Assistant Secretary for Research, Development and Simulation in the Office of Defense Programs, sent a letter to the Board forwarding the FY2000 first quarterly status report for the 97-2 implementation plan. 
- On March 1, 2000, the Director, Safety Management Implementation Team, sent a letter to the Board forwarding a report on the Department's Corrective Action Tracking System (CATS) which is a deliverable under the 98-1 implementation plan.

- On March 1, 2000, the Deputy Assistant Secretary for Integration and Disposition in the Office of Environmental Management, sent a letter to the Board regarding the Hanford polycube stabilization commitment under the 94-1 implementation plan revision 2.

- On March 16, 2000, the Director of the Safety Management Implementation Team sent a letter to the Board enclosing the Department's response to a Board letter dated February 16,2000 , requesting additional information on presentations and material submitted at a public meeting on January 20, 2000.

- On March 27, 2000, the Assistant Deputy Administrator for Military Application and Stockpile Operations, Defense Programs, sent a letter enclosing a copy of the Department's pit storage container surveillance program plan under commitment 5.3.1 per the 99-1 implementation plan.

- On March 31, 2000, the Acting Deputy Administrator for Defense Programs, sent a letter to the Board responding to a Board letter dated December 1, 1999, regarding issues raised on authorization basis complexity and integration in relation to Recommendation 98-2.

- On April 3, 2000, the Acting Deputy Administrator for Defense Programs, sent a letter to the Board responding to a Board letter dated November 9, 1999, regarding the safety management deficiencies and project management at the Y-12 Plant.

- On April 25, 2000, the Acting Deputy Administrator for Defense Programs, sent a letter to the Board responding to a Board letter dated December 6, 1999, regarding DNFSB/TECH-24 - Safe Handling of Insensitive High Explosive Weapon Subassemblies at the Pantex Plant.

- On April 27, 2000, the Secretary sent a letter informing the Board that Revision 3 for Implementation Plan 94-1 and the Department's Implementation Plan for Recommendation 2000-1 will be submitted to the Board by the end of May 2000.

- On April 28, 2000, the Manager of the Albuquerque Operations Office, sent a letter to the Board enclosing deliverables per the 98-2 implementation plan. 


\section{Annual Report to Congress}

- On May 3, 2000, the Deputy Secretary sent a letter to the Board responding to a Board letter dated March 2,2000, regarding the quality of authorization bases at defense nuclear facilities.

- On May 10, 2000, the Acting Assistant Deputy Administrator for Research, Development, and Simulation, Defense Programs, sent a letter to the Board enclosing the 97-2 quarterly status report for the second quarter, FY2000.

- On May 17, 2000, the Secretary sent a letter to the Board responding to a Board letter dated March 7, 2000, concerning the low dose radiation research program.

- On May 18, 2000, the Assistant Secretary for Environmental Management sent a letter to the Board responding to a Board letter dated February 29, 2000, regarding the inaccurate and incomplete information received on the Hanford Spent Nuclear Fuel Project.

- On June 8, 2000, the Secretary sent a letter to the Board enclosing the Department's implementation plan for remediating the nuclear materials identified in Recommendations 94-1 and 2000-1.

- On June 9, 2000, the Deputy Assistant Secretary for Integration and Disposition, Office of Environmental Management, sent a letter to the Board reporting completion of the final Idaho commitment found in the Department's implementation plan for Recommendation 94-1.

- On June 12, 2000, the Assistant Secretary for Environmental Management sent a letter to the Board enclosing an Issue Resolution Paper regarding the K-Area Materials Storage Facility in response to the Board's March 9, 2000 letter.

- On June 26, 2000, the Departmental Representative sent a letter to the Board enclosing copies of the Workshop Results Summary for the Department's Facility Representatives Annual Workshop that was held on May 16-18, 2000.

- On June 30, 2000, the Deputy Assistant Secretary, Office of Oversight, Environment, Safety and Health, sent a letter to the Board enclosing the Office of Oversight Safety Issue Corrective Action Process Procedure, a supplement to the 98-1 implementation plan.

- On July 3, 2000, the Acting Deputy Administrator for Defense Programs, sent a letter to the Board responding to a Board letter dated May 2, 2000, on fire hazard analysis for W76 disassembly and inspection and fire response of certain canned sub-assemblies. 
- . On July 3, 2000, the Acting Deputy Administrator for Defense Programs, sent a letter to the Board responding to a Board letter dated March 29, 2000, on fire protection program at the Pantex Plant.

- On July 7, 2000, the Amarillo Area Office Manager sent a letter to the Board enclosing a summary of near-term compensatory actions taken at Pantex related to a potential safety issue associated with Canned Sub-Assemblies (CSA).

- On July 14, 2000, the Acting Deputy Administrator for Defense Programs, sent a letter to the Board responding to a Board letter dated May 24, 2000, regarding the recovery of Los Alamos National Laboratory from the Cerro Grande fire.

- On July 17, 2000, the Assistant Secretary for Environmental Management sent a letter to the Board enclosing a copy of a memorandum from the Savannah River Site's Assistant Manager for High-Level Waste to the Westinghouse Savannah River Company that conveys the Department's expectations for the proposed strategy for the disposition of the current Tank 49 material.

- On July 21, 2000, the Albuquerque Operations Office Manager sent a letter to the Board providing an update on deliverables per the 98-2 implementation plan.

- On July 30, 2000, the Deputy Administrator for Defense Programs sent a letter to the Board enclosing the Department's response to Board letters dated March 30, 2000, and May 30, 2000, regarding design and construction of the Hydrogen Fluoride Supply System project at the Y-12 Plant in Oak Ridge, Tennessee.

- On August 16, 2000, the Deputy Assistant Secretary for Integration and Disposition, Office of Environmental Management, sent a letter to the Board reporting completion of four commitments in the Department's 2000-1 Implementation Plan.

- On August 17, 2000, the Assistant Secretary for Environmental Management sent a letter to the Board designating Mr. Ralph Erickson, effective August 7, 2000, as the Responsible Manager for the implementation of Recommendation 96-1.

- On August 18, 2000, the Assistant Deputy Administrator for Military Application and Stockpile Operations, Defense Programs, sent a letter to the Board enclosing a copy of the Pantex Plant Sealed Insert Third Quarter Fiscal Year 2000 Summary Status Report per the 99-1 implementation plan.

- On August 21, 2000, the Secretary sent a letter notifying the Board that the Department will require an additional 45 days to transmit the 2000-2 implementation plan. 
- On August 22, 2000, the Deputy Secretary of Energy sent a letter to the Board regarding Board letter dated June 30, 2000, on the independent assessment of the Federal Technical Capability Program.

- On August 24, 2000, the Acting Assistant Manager for High Level Waste, Savannah River Operations Office, sent a letter to the Board regarding recommendation 96-1, disposition of Tank 49 Material.

- On August 28, 2000, the Assistant Deputy Administrator for Military Application and Stockpile Operations, Defense Programs, sent a letter to the Board enclosing the revised program directives governing the composition and functioning of the Nuclear Explosive Safety Study Group (NESSG) in compliance to commitment 5.4.2(c) of the 98-2 implementation plan.

- On September 6, 2000, the Assistant Secretary for Environmental Management sent a letterito the Board responding to a Board letter dated August 18, 2000 on the Americium/Curium Vitrification Project at the Savannah River Site.

- On September 8, 2000, the National Nuclear Security Administrator sent a letter to the Board enclosing a report on the Department's path forward for correcting the deficiencies of authorization bases at the Y-12 Plant.

- On September 18, 2000, the Deputy Secretary forwarded a Memorandum to the Heads of Departmental Elements on the continuation of nuclear criticality safety initiatives.

- On September 18, 2000, the Deputy Secretary forwarded a Memorandum to the Heads of Departmental Elements regarding the Nuclear Criticality Safety Workshop which will be held in Albuquerque, NM, beginning October 23, 2000.

- On September 25, 2000, the Secretary sent a letter to the Board enclosing the 98-2 implementation plan, revision 1 .

- On September 26, 2000, the Director, Office of Engineering and Construction Management, sent a letter to the Board regarding draft DOE O 413.X, Project Management for the Acquisition of Capital Projects.

- On September 27, 2000, the Deputy Assistant Secretary for Integration and Disposition, Office of Environmental Management, sent a letter to the Board enclosing closure packages for several commitments per the 2000-1 implementation plan. 
- On September 29, 2000, the Secretary sent a letter to the Board relative to the Department's implementation plan for the stabilization of nuclear materials identified in Recommendation 2000-1.

- On October 19, 2000, the Principal Deputy Assistant Secretary for Environment, Safety and Health sent a letter to the Board providing information regarding commitment 26 , due November 2000 per the 2000-2 implementation plan.

- On October 23, 2000, the Richland Operations Office Manager sent an appreciation letter to the Board for Mr. Steve Stokes, for serving in the positions of Board staff representative and Cognizant Engineer at the Hanford Site.

- On October 26,2000, the National Nuclear Security Administration Administrator sent a letter responding to a Board letter dated August 30,2000 relative to the preparations for the resumption of the enriched uranium reduction process at the Y-12 Plant.

- On October 31,2000, the Acting Deputy Administrator for Defense Nuclear Nonproliferation, Office of the National Nuclear. Security Administration Administrator sent a letter to the Board regarding the Pit Disassembly and Conversion Facility filter system.

- On October 31, 2000, the Albuquerque Operations Office Manager sent a letter to the Board providing information regarding five deliverables due October 2000 per the $98-2$ implementation plan.

- On October 31, 2000, the Deputy Assistant Secretary for Integration and Disposition, Office of Environmental Management, sent a letter to the Board reporting completion and requesting closure of a commitment outlined in the 2000-1 implementation plan.

- On November 3, 2000, the Assistant Secretary for Environmental Management sent a letter to the Board responding to a Board letter dated September 20,2000 regarding the closure to support safe and reliable operation of the Hanford Spent Nuclear Fuel (SNF) Project facilities.

- On November 3, 2000, the Deputy Administrator for Defense Programs sent a letter to the Board enclosing a memorandum detailing the Department's actions to date and the planned path forward on issues raised by the Board's staff regarding the Chemical Safety Program and various chemical safety issues at the Y-12 Plant. 
- On November 17, 2000, the Deputy Administrator for Defense Programs sent a letter to the Board enclosing status of actions taken to address issues mentioned in the Board's staff issue report entitled, "Review of Fire Protection Program at Pantex Plant.

- On November 17, 2000, the Assistant Deputy Administrator for Military Application and Stockpile Operations, Office of Defense Programs sent a letter to the Board enclosing the Final Change Order (FCO) requiring the use of Inconel 718 capscrews to secure the flange on the AL-R8 Sealed Insert under Commitment 5.1.1 per the 99-1 implementation plan.

- On November 18, 2000, the Assistant Deputy Administrator for Military Application and Stockpile Operations, Office of Defense Programs sent a letter to the Board regarding a Board letter dated September 21,2000, regarding a classified report of a Board staff review of the "Y-12 W56 Dismantlement Campaign (U)."

- On November 22, 2000, the Deputy Assistant Secretary for Integration and Disposition, Office of Environmental Management sent a letter to the Board reporting completion of two commitments per the 2000-1 implementation plan.

- On November 30, 2000, the Assistant Secretary for Environmental Management sent a letter to the Board responding to a Board letter dated August 29, 2000, regarding Hanford high-level waste storage tank integrity.

- On November 30, 2000, the Albuquerque Operations Office Manager sent a letter to the Board providing information on three deliverables due November 2000 per the 98-2 implementation plan.

- On December 6, 2000, the Assistant Secretary for Environmental Management sent a letter to the Board regarding the start of fuel removal operations from the K-Basins.

- On December 6, 2000, the Richland Operations Office Manager sent a letter to the Board documenting plans and rationale for closing out the concerns discussed during a December 6,2000, videoconference regarding start of fuel processing operations.

- On December 7, 2000, the Deputy Administrator for Defense Programs sent a letter to the Board providing a delivery date for the site-wide action plan which will address the issues raised in a Board letter dated August 18, 2000.

- On December 7, 2000, the Assistant Secretary for Environment, Safety and Health sent a letter to the Board regarding the DNFSB/Tech-27, "Fire Protection at Defense Nuclear Facilities." 